\title{
Preliminary Notes on the Term and Institution of al-Shākiriyya in Early Islam (ca. 14-218 H/635-36-833 CE) Mainly According to the Arabic Sources
}

\begin{abstract}
The aim of this paper is to study the nature of the term and institution of al-Shākiriyya by re-examining the Arabic sources pertaining to the Umawi and early 'Abbāsī caliphate. It is difficult to discern the character of the Shākiriyya in the service of the Arab commanders in Central Asia from the Arabic sources. They provide no information on ethnic composition, mobilization, military training or potential ties between a commander/master and his Shākir. This applies mainly to the Umawī period, but also to the first 'Abbāsī period up to al-Ma'mūn's rule (813-833). It is also impossible to determine from them the possible connections between the ancient Central Asian military institutions and military institutions in the Islamic world. From evidence about the Shäkiriyya in the Arabic sources we can usually discern a distinct military character, though it is noteworthy that in some cases the term Shākiri can be translated as meaning a loyal adherent, or even a servant. While relatively extensive, the evidence at hand from the Umawī and the early 'Abbāsī periods is too limited to fully demonstrate that a) the Shäkiriyya units denote Turks and b) that these allegedly Turkish units performed their service for the 'Abbāsī caliphs according to concepts and practices derived from the Central Asian steppe.
\end{abstract}

Keywords: Shākiriyya; Umayyads; early 'Abbāsids; early Islamic army; early Islamic history and historiography

\section{Introduction}

During my current study of al-Ma'mūn's army in Khurāsān, I came upon several pieces of evidence relating to a corps of Shākiriyya at al-Ma'mūn's court in Marw. In checking the nature of the term and institution in the Arabic sources, I naturally went back in history to the Umawi period and even earlier, to the period of

A shorter preliminary version of this paper was read at the workshop on The Origin and Early Nature of Military Slavery in the Islamic World held at the Hebrew University in memory of the late Prof. David Ayalon (17-22 December 2008).

2 OpenAccess. (C) 2020 Amikam Elad, published by De Gruyter. (cc) BY-NC-ND This work is licensed under the Creative Commons Attribution-NonCommercial-NoDerivatives 4.0 License. 
the Arab conquest. I am now in the preliminary stage of processing the material so gathered. However, the Arab sources I examined are for the most part not decisive. It is difficult, if not impossible, to determine the characteristics of the contemporary Shākiriyya from them.

\section{A Brief Summary of Scholarly Views Regarding al-Shākiriyya}

Barthold commented that the Shākiriyya is sometimes mentioned in Arabic sources as a ruler's personal guard. He presents several examples related to Transoxania, according to which non-Arab rulers and also some tribal leaders and senior Arab commanders possessed a guard of this type. ${ }^{1}$ Barthold argued that the origin of the word is the Persian chākar (literally, servant). ${ }^{2}$ This seems to be the accepted opinion among some scholars. ${ }^{3}$ From Narashakhī's description of the queen of Bukhārā's court, it seemed to Barthold that the Shākiriyya was a kind of honour guard. It included young noblemen sent in mutual exchange from the courts of other rulers, like the sons of European knights who served at the courts of their kings and dukes. ${ }^{4}$

Shaban described this institution as an Iranian one in its origin, agreeing that the root of the word is Persian and its meaning is servants. ${ }^{5}$ He argued in a similar vein to Barthold (but without citing him) that the Shākiriyya performed the same military service for their leaders that European knights in the Middle Ages did for their kings. In the 'Abbāsī period, primarily in that of al-Mu'tașim, this institution was transferred from the east to the heart of the caliphate. Many leaders and local princes from the east joined al-Mu'tașim. Following ancient customs prevalent in the east, their loyal followers accompanied them and created the Shäkiriyya regiments, as a way to continue to serve their leaders in the heart of the empire when those leaders became mawāli of the ruler. Others came individually and joined the Shäkiriyya of the ruler himself. Shaban brings a string of references to prove his claims. However, though these references mention the Shäkiriyya, most of them are from the period of al-Mu'tașim and onward.

\footnotetext{
1 Al-Ṭabarī, Ta'rīkh, 2, 1159 [= Barthold 1928, 180]: the year 85 H/704-705 CE, the Shākiriyya of Țarkhūn, the king of Samarqand, ruler of Sordia, see no. B/4, below; al-Ṭabarī, Ta'rīkh, 2, 1155: an Arab tribal leader of Khuzā'a, see no. B/3, below.

2 Barthold 1928, 180.

3 E.g., Beckwith 1984, 38, note 43: "the word is merely the Arabicized form of Persian chākar;" Yonggyu 2004, 40.

4 Barthold 1928, 180 (quoting Narshakhī, Ta'rīkh Bukhārā, pp. 7-8 [= Frye 1954, 9]).

5 Shaban 1976, 2: 64-65, quoting the translation of al-Marwazì in Minorsky 1942, 18.
} 
They do not provide enough information to justify Shaban's broad and detailed explanation. ${ }^{6}$

Forand argued that the Shākiriyya of the Iranian/Soghdian princes and rulers in Central Asia mentioned by the Arabic sources denotes "corps of slaves" and that it is "impossible to establish beyond a doubt that individuals constituting a shākiriyya among the Umayyads [governors and senior commanders] were of servile status."

Beckwith argues for a Central Asian (Soghdian) origin of the institution of alShākiriyya, and this has been accepted by some scholars. ${ }^{8}$ He quotes Chinese sources of the period describing the chākars' Turkish and Soghdian guard corps as courageous and fierce warriors. ${ }^{9}$ More comprehensive studies in this vein have been carried out by Yonggyu and (recently) De La Vaissière (see below).

From a single Arabic passage where a Turkish general says: "I am the slave ('abd) of the Khāqān from his Shākiriyya,"'10 Beckwith concludes that:

...the relationship between lord and chākar was extremely close indeed; al-Iskand's ally Ghūrak, the king of Samarkand, speaks of his feudal relationship to his Western-Turkic liege-lord...It appears, therefore that the members of the central Asian guard corps spoke of themselves as the slaves of their lord [my emphasis].

We need more than one (equivocal) piece of evidence to corroborate such a social-cultural and ethnic institution, despite Beckwith's lively depiction.

Yonggyu is more cautious in his definitions. Regarding the above evidence, he believes that the word "slave" (' $a b d$ ) is used here metaphorically and does not denote "simple slaves." 11 Chākars "often labelled themselves as their lords' slaves, even if mostly metaphorically and nominally."12 Yonggyu brings

6 Shaban 1976, 2: 64-65, quoting al-Ṭabarī, Ta'rīkh, 3, 8, 928, 1373, 1427, 1605; Ibn al-Athīr, alKāmil (ed. Tornberg), 7, 32; Ibn A'tham al-Kūfî, Kitāb al-Futūh, 2, fol. 271a [= ed. Hyderabad, 8, 331].

7 Forand 1962, 10-11.

8 Beckwith 1984, esp. 39-40; Yonggyu 2004, chapter one, esp. 39-75; De La Vaissière 2007, esp. 59-158.

9 Beckwith 1984, 37: Chinese sources describing the chākars in Bukhārā and Samarqand; the word chākar in the Chinese sources is che-chieh (Beckwith 1984, 37, nn. 41 and 42); I cannot judge these pieces of evidence.

10 Al-Ṭabarī, Ta'rīkh, 2, 1542: أنا عبد الخاقان من شاكريته; see the discussion of Yonggyu below.

11 Yonggyu 2004, 63: "Indeed they are not simple slaves, because they are also of the highest echelons of society."

12 Yonggyu 2004, 63. 
several pieces of evidence from Chinese sources (some from the $7^{\text {th }}$ century), where the chäkars of the Turkish qaghan are called "slaves of the qaghan," denoting in his view subordinates. ${ }^{13}$ Regarding Forand's assertion that "the Shäkiriyyah of the Iranian rulers must have been slaves," ${ }^{14}$ Yonggyu argues that this conclusion "is somewhat extreme...it is probable that the chäkars in Iran and Central Asia were fully subordinate to their rulers and that they were servile elements in the service of the rulers." ${ }^{~} 15$ It is noteworthy that Beckwith speaks only of Central Asia while Yonggyu distinguishes between Iran and Central Asia. Yonggyu adds (following Forand's examples) that al-Ṭabarī provides many examples showing that the Iranian ruler had the "right of life and death over the members of shākiriyya." But this assertion cannot be proved from the texts he adduces. ${ }^{16}$

\section{Some Major Characteristics of al-Shākiriyya in Central Asia.}

Yonggyu asserts that Chinese sources from the $7^{\text {th }}$ century attest to special military forces called chākars.

...inner Asian historians and Sinologists have in general regarded the term as referring to the elite armed forces constituted by Central Asian Turko-Persian ethnic groups. ${ }^{17}$...Other currently available sources in Chinese also indicate that chākars are peoples associated to Iranian groups. ${ }^{18}$

The military skills, courage and extreme loyalty of the chākars are well attested to and demonstrated in the Chinese sources. ${ }^{19}$ Unfortunately, Yonggyu adds, "The Chinese sources are not forthcoming when it comes to the question of by what mechanism such a special bond between the inner Asian ruler and his retainers was created." ${ }^{20}$ The same can be said about the Arabic sources pertaining to the Umawī and the early 'Abbāsī caliphate.

13 Yonggyu 2004, 63.

14 Forand 1962, 11.

15 Yonggyu 2004, 68.

16 Yonggyu 2004, 68, quoting Forand 1962, 11, citing al-Ṭabarī, Ta'rỉkh, 2, 965, 1155, 1609, 1927 (nos. B/1, B/3, B/11 and B/15 in this paper).

17 Yonggyu 2004, 44-45.

18 Yonggyu 2004, 46.

19 Yonggyu 2004, 68-69.

20 Yonggyu 2004, 70. 


\section{De La Vaissière's Conclusions}

De La Vaissière devotes large parts of a recent book to a broad in-depth discussion of the Shäkiriyya. He expands some of the conclusions of Beckwith and more especially of Yonggyu, arguing that the Shäkiriyya was strictly a special institution within the Soghdian armies in Transoxania. ${ }^{21}$ In his view the professional soldiers called chākar constituted "the most specific element of the military Soghdian life."22

De La Vaissière relies mainly on two groups of Chinese and Arabic sources. The Chinese sources enable him to establish unequivocally that the chākars were "an elite guard restricted to a few selected companions."23

Les chākar étaient les soldats d'élites des nobles et des rois, distingués par leur bravoure, entretenus, éduqués et adoptés fictivement par eux afin de s'assurer de leur fidélité. Ils les suivaient à la guerre comme dans le service quotidien. La plupart d'entre eux devaient être des gens du commun, mais des rois pouvaient avoir des chākar nobles. ${ }^{24}$

\section{Persian or Soghdian Origin?}

Unlike some of the scholars that preceded him, De La Vaissière argues against the Persian-Sasanian origin of this institution via the word itself. The etymology of the word is from the Soghdian and not the Persian language; although it does not appear in known Soghdian sources (mostly religious texts), it is found in the Arabic and the Chinese sources. ${ }^{25}$ All the Arabic (almost exclusively from al-Tabarī) and the Chinese sources that mention the Shākiriyya pertain to Central Asia (Transoxania). Al-Ṭabarī never mentions these units in his descriptions of the Arab conquests of the Sasanian territories. ${ }^{26}$

De La Vaissière admits that the word chākar does appear in $10^{\text {th }}$ century Persian texts (for example, Narshakhī), but unlike Barthold ${ }^{27}$ he argues that the meaning of the word is servant or apprentice and that it refers to an institution

21 De La Vaissière 2007, 59.

22 De La Vaissière 2007, 68: "Les soldats professionnels nommés chākar forment l'élément le plus spécifique de la vie militaire sogdienne."

23 De La Vaissière 2007, 69-70: "d'une garde d'élite restreinte à quelques compagnons choisis."

24 De La Vaissière 2007, 86.

25 De La Vaissière 2007, 68.

26 De La Vaissière 2007, 72-73.

27 See above. 
basically different from that of the chākars of Central Asia. ${ }^{28}$ The main difference between the chākars of Transoxania and Narshakhī's chākars is the inferior social status of the latter. According to the Zoroastrian point of view, they are nonnoble servants performing base work. The descriptions of the court of the Queen of Bukhārā by Narshakhī are completely different from the military institution of the chākars depicted in the Chinese sources. ${ }^{29}$

The difference between the meaning of the term chākar in the Persian versus the Arabic and Chinese texts explains (in De La Vaissière's opinion) the apparently single text of al-Muțahhar b. Țāhir al-Maqdisī (Kitāb al-Bad' wa-l-ta'rīkh) in which he describes the Shäkiriyya units in the army of the Sasanian general Rustam during the battle of al-Qãdisiyya in the year 15 H/636 CE. ${ }^{30}$ This conclusion poses some difficulties.

A) There is a similar text recorded by al-Ṭabarī (no. 1): "The army of Rustam consisted of one hundred and twenty thousand men. Sixty thousand were accompanied by Shākiri men; and from among these sixty thousand fifteen thousand noblemen (also) were accompanied." 31

B) The term al-Shākiriyya in different forms (e.g., wa-Shākiriyyatuhu) appears at least two more times in Ibn Țāhir's book in connection with two different periods of the 'Abbāsī caliphate 1) In the year $136 \mathrm{H} / 754 \mathrm{CE}$, the Shākiriyya of caliph Abū l-'Abbās al-Saffāh (r. 132 H/749 CE-134 H/756 CE) is mentioned in al-Kūfa/alHāshimiyya. ${ }^{32}$ (No. C/3 [20]) 2) The mawālī and the Shākiriyya in Sāmarrā' rebelled during the short reign of caliph al-Musta în (Ahmad b. Muhammad b. al-Mu'tașim; r. 248 H/862 CE-252 H/866 CE) due to the latter’s political deeds, among them the imprisonment of al-Mutawakkil's two sons al-Mu'tazz and al-Mu'ayyad and the release of al-Hasan b. al-Afshīn from prison. ${ }^{33}$

28 De La Vaissière 2007, 88.

29 De La Vaissière 2007, 74-75.

30 De La Vaissière 2007, 73, and note 194, quoting Zakeri 1995, 184; “on peut assurer que lorsque Maqdisī decrit des chākar parmi les suivants de Rostam et de Yazdergerd III durant la bataille de Qadissiyya, dans son Livre de la création et de l'histoire, il se sert simplement d'un mot commun à Balkh au $\mathrm{X}^{\mathrm{e}}$ siècle pour décrire des serviteurs de souverains sassanides très différents des chākar centre-assiatiques et qui, dans l'Iran sassanide portaient certainement un autre nom." 31 Al-Ṭabarī, Ta’rîkh, 1, 2258 : وكان جنده مائة و عشرين ألفا: ستين ألف متبو ع مع الرجل الثاكري, ومن الستين ألفا خمسة عنبر ألف شريف متبوع.

32 Al-Muțahhar b. Țāhir, al-Bad', 6, 76, records a tradition relating the plot by the caliph and his brother al-Manșūr to assassinate Abū Muslim; the caliph backs down from his decision, ordering one of his Shākiriyya (فقال لبعض شاكرينة) to tell his brother not to kill Abū Muslim.

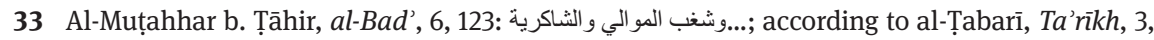
1533, al-Hasan was released from prison in $250 \mathrm{H} / 864 \mathrm{CE}$. The insurrection against al-Musta'in and the release of al-Mu'tazz from prison occurred in $251 \mathrm{H} / 865 \mathrm{CE}$ (al-Ṭabarī, Ta'rīkh, 3, 1545; 
C) It is difficult to accept the historiographical method applied by De La Vaissière to al-Muțahhar b. Tāahir's work in general and to this specific text in particular. Al-Muțahhar b. Țāhir was a native of Jerusalem, a contemporary of the famous geographer Muhammad b. Abī Bakr (known as al-Muqaddasī/alMaqdisī, d. ca. 1000). Al-Muțahhar b. Ṭāhir emigrated from Jerusalem to Bust in Sijistān, where he wrote his book around 355 H/966 CE (not in Balkh as De La Vaissière believes). Very little information survives regarding him; it is not known exactly when he left Jerusalem and when he settled in Bust. ${ }^{34}$ His work was written in Arabic, not in Persian.

the rebels referred to are Turks). I did not find the expression al-mawāli wa-l-Shākiriyya in alTabari’s work, but this phrase does appear even earlier in other sources, e.g. during al-Mutawakkil's reign (r. $232 \mathrm{H} / 847 \mathrm{CE}-247 \mathrm{H} / 861 \mathrm{CE}$ ), when the latter ordered the preparation of an extraordinary celebration in honour of his young son, al-Mu'tazz, who had finished learning and reciting the Qur'ān. This unprecedented celebration was held in Barkuwārā, one of al-Mutawakkil's palaces. See al-Mu'āfā b. Zakariyyā', al-Jalīs al-Șāliḥ, 3, 103-105; 105: "he [the caliph) ordered the most prominent dignitaries, the most distinguished mawālī and al-Shākiriyya to be present in

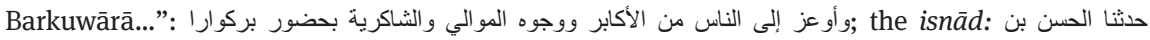

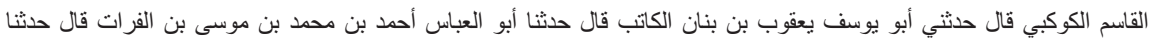
(أبي وجماعة من شيوخنا ; Ahmad b. Muhammad b. Mūsā (236 H/850-851 CE-291 H/904 CE) belonged to the famous Banū l-Furāt family, several of whose members held the offices of secretaries and viziers under the 'Abbāsīs (mainly from the end of the $3^{\text {rd }} / 9^{\text {th }}$ century) and the Ikhshīdīs (in the 4 th $/ 10^{\text {th }}$ century). They were pro-Shī'a. On Banū l-Furāt, see D. Sourdel, "Ibn al-Furāt", The Encyclopedia of Islam, new edition, 3, s.v. (on Ahmad and his father, see p. 767b.), but esp. Sourdel 1959-60 (index); for parallel sources for the tradition, see for example Ibn al-'Imrānī, al-Inbä', 1, 118-119 and 281, n. 285, an exhaustive bibliography; Ibn al-'Adīm, Bughya, 8, 3764-3765; Ibn 'Asākir, Ta'rīkh, 18, 314-316. On Barkuwārā, see Yāqūt, Mu jam (Beirut ed.), 1, 410; Le Strange 1905, 52. See also al-Ṭabarī, Ta'rīkh, 3, 1627, where we find the phrase al-atrāk wa-l-mawā̄ì (in al-Musta'īn's army); Gordon 2001, 224, n. 242, argues that the mawāl mentioned here are Turks as well: "there is good reason to think Turks are meant here as well. In other words, a distinction is made here between two groups of Turks." See also al-Ṭabarī, Ta'rīkh, 3, 1582 (year 251 H/865 CE): "The Shākiriyya and the Abnā' [contingents] support[ed] al-Mu'tazz while the Turks

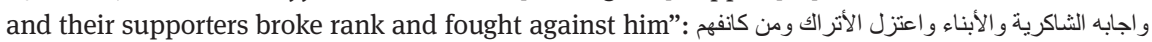
وحاربوه It is noteworthy that there is a distinction here between the Shākiriyya and the Turks; for the involvement of the Shäkiriyya corps in the civil war, see for example, Saliba 1985, index ("Shākiriyyah"); for a historical survey of the civil war, see Shaban 1976, 2: 80-85, but esp. Gordon 2001, 90ff., and 224, n. 238 for further bibliography.

34 Kitāb al-Bad' wa-l-ta'rīkh was for a long time ascribed to Abū Zayd Ahmad b. Sahl al-Balkhī (d. 322 H/934 CE), mainly due to the assertion of Hājīi Khalīfa in Kashf al-zunūn, 1, 227, but see also Ibn al-Wardī, Kharīda, 249 (mentioned by Morony 1988, 353); van Ess 1978, 322 (S. 581); Adang 1996, 49. On al-Muțahhar b. Țāhir al-Maqdisī (a brief mention of the author and his book), see Goitein 1982, 192-193 (the original Hebrew version of this article appeared in 1953); Sarkīs 1928-30, 1: 241-242; al-Zirikli 1980, 1: 133-134, 7: 253, 8: 285; Kaḥhāla 1957-61, 12: 294; “Al-Muțahhar b. Țāhir,” p. 762a; GAL, I, p. 337; S. I, p. 222; Sezgin 1967, 1: 337; Rosenthal 1968, 
[It] recalls al-Mas'ūdī's Murūj [al-Dhahab], but history here is envisaged from a more philosophical and certainly from a more critical point of view. The author displays a good knowledge of ancient and alien religions, whose cultural value he stresses without however ceasing to place Islam above them. He follows the usual order. Beginning with the creation of the world, he devotes the first three volumes (half of the whole work) to ancient history and to philosophical, theological, geographical, etc. considerations and does not reach a consideration of Islam until the fourth volume (cf. the parallel lay-out of al-Mas'ùdì's work, in which these earlier topics occupy only two volumes out of five), finally reserving a restricted place for the Umayyads and 'Abbāsīds....Such a disdain may possibly arise precisely from the originality and free thought of a writer who seems to have maintained a certain independence and not to have been an adherent of any religious movement of the age when he lived..$^{35}$

The historical parts of this work preserve many pieces of evidence of utmost importance, which are not found in other sources known to me. ${ }^{36}$

In the introduction to the historical section of his work, the author asserts that it "is based on what we have found in the books of the authors of history (في كتب أهل الأخبار)." From a cursory reading it is clear that Ibn Ṭāhir relied heavily on earlier sources, including well-known works such as al-Ṭabarīs (or his sources; this should be established by a special study). ${ }^{37}$ Many times he quotes written works or transmitters from which he accumulated his historical information. This is done according to the traditional methodology of the great historical written Arabic works. The examples are numerous and it is sufficient to cite only a few here. ${ }^{38}$

From a cursory check of Ibn Tāhir's work al-Bad' wa-l-Ta'rīkh it is clear that he was very learned in hadith, fiqh, historical and other kinds of Islamic literature. The sections of pre-Islamic history that deal with al-mabda' and qișas alanbiy $\bar{a}^{\prime}$ until the beginnings of Muhammad's mission, the life of the Prophet

index, esp. 114-115; Khālidī 1976. Khālidī quotes the short mention of the author by Sezgin, Rosenthal and Miquel (see the bibliographical citation above in this note); Miquel 1967, 1: 212-217, and index; see also Khālidī 1994, 153-154; Adang 1996a, esp. pp. 48-50, and index; Adang 1996b, esp. 59-60; Morony 1988.

35 “Al-Muțahhar b. Ṭāhir.” But see Khālidī 1976, who considers him a Mu'tazilī.

36 See the short evaluation of the man and his work in this vein by Sezgin 1967, 1: 337 (quoted in Gil 1992, 421).

37 For example, compare al-Muțahhar b. Țāhir, al-Bad', 6, 75-76, to al-Ṭabarī, Ta'rīkh, 3, 85-86 (partly related by al-Ṭabarī from al-Madā'inī); see full discussion below ('Abbāsīs, no. C/3 [20])

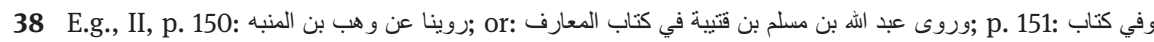

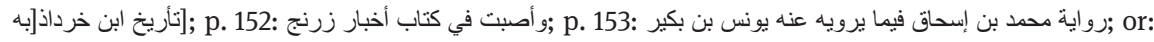

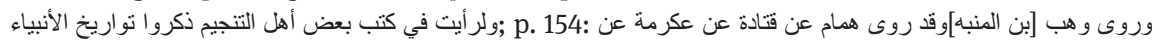

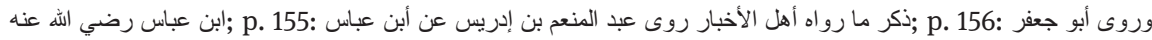

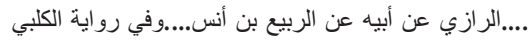


and the history of the caliphate are written in the familiar tradition of the important Islamic historians of the $9^{\text {th }}$ and $10^{\text {th }}$ centuries. Even an anecdote about an alleged disputation between the chief commander of the Arab force in front of Yazdajird (no. A/1.3, below), is written in accordance with the style, spirit and contents of many of the traditions of the early Arab-Muslim conquests, as found in the early Arabic Futūh literature-for example, the works of Abū Mikhnaf (d. $157 \mathrm{H} / 774 \mathrm{CE}$ ), al-Azdī (d. around $190 \mathrm{H} / 805-806 \mathrm{CE}$ or $210 \mathrm{H} / 825-826$ CE), al-Qudāmī (d. between 201 H/816-17 CE or 210 H/826-27 CE), Muhammad b. 'A' idh (d. 232 H/847 CE) or Sayf b. 'Umar (d. ca. 184 H/800 CE). Tāhir seldom quotes his historical sources in these early sections. Although his work has long been edited and used in research, it has not been properly studied; I do not know of an in-depth study of the author or his important work. ${ }^{39}$

Though it is tempting to compare the Shäkiriyya and the institution of knighthood in the European Middle Ages (as argued by Barthold and Beckwith ${ }^{40}$ ), there should be reservations regarding the equation. It is refuted, for example, and treated with great caution and reservation by De La Vaissière. ${ }^{41}$ If such comparisons are made, they should be put forward in great detail and with profound caution. The regimes in the east and in the west were very different in character. ${ }^{42}$

Other researchers mention the Shākiriyya but do not discuss it or attempt to clarify its character. ${ }^{43}$

\section{The Term Shākirī/Shākiriyya in the Arabic Sources}

Used to mean military contingents: marked MC

39 See Khālidī 1976, 2.

40 Beckwith 1984, 35 and note 26: comparing the Shākiriyya guard corps with "the system found among the Germanic peoples of late Classical and early medieval Europe," the comitatus. 41 De La Vaissière 2007, 83-84, argues against Beckwith but mainly against two articles by P. Golden from 2001 and 2004 (not read by A. E.).

42 For example, see the reservations of Cahen and Lambton in their discussion of the iqta $\bar{a}$ regime in the east and attempts to compare this regime with European feudalism, Lambton 1965; Cahen, "Ikțâ̄"', $E I^{2}, 3,1088-1091$.

43 Pipes 1981, 137, note 215; Lassner 1980, 136 (regarding al-Mu'tașim’s period). Levy 1969, 418 419, translates the Shākiriyya of al-Mutawakkil (847-861) as referring to new recruits in contrast to the old regiments. He was mistaken in his understanding of the term. In relation to the citation (al-Ṭabarī, Ta'rīkh, 3, 1510) according to which al-Abnä' wa-l-Shākiriyya rebelled against the Turks, he believes that $A b n \bar{a}$ ' means "sons", that is, new recruits. What is meant here are in fact the veteran $A b n \bar{a}$ ' regiments. 
Used to mean non-military, servant or slave: marked NM/SE/SL

\section{A) The Period of the Conquest of al-'Irāq (14 H/636 CE): MC? Instead of S/: SE/NM?}

These may be the earliest pieces of evidence at our disposal, recording the term Shākiriyya/Shākiri as in use in the year $14 \mathrm{H} / 636 \mathrm{CE}[!]$, during the battle of alQādisiyya in al-'Irāq. Two versions of these terms appear in the sources. Both describe the army of Rustam, the chief general of the Persian army.

\section{A/1) The First Version, According to Tabarī}

This version is recorded by al-Tabarī from Sayf b. 'Umar (d. ca. 184 H /800 CE), who transmitted the following tradition from three informers: "The army of Rustam consisted of one hundred and twenty thousand men. Sixty thousand were accompanied by the Shākiri man; and from among these sixty thousand fifteen thousand noblemen (also) were accompanied."44 Friedmann renders the term Shākirī in this sentence as "servant:" "The army of Rustam consisted of one hundred and twenty thousand men. Sixty thousand were accompanied by servants (shākirī); from the [other] sixty thousand, fifteen thousand were noblemen accompanied [by dependents].”45

In another place, al-Ṭabarī (via Sayf b. 'Umar) records: "Rustam set out with one hundred and twenty thousand men, all of them accompanied by dependents. Together with their dependents they numbered more than two hundred thousand. He set out from al-Madā'in with sixty thousand men, accompanied by dependents." ${ }^{46}$ In this version the Shākiriyya are not mentioned.

\section{A/1.2) The second version, According to Kitāb al-Bad' wa-l-Ta'rīkh}

"Rustam arrived and encamped in al-Hīra at the head of sixty thousand regular (paid) soldiers, besides (the accompanying units) of the supporters, the followers

44 Al-Ṭabarī, Ta'rīkh, 1, 2258: وكان جنده مائة و عشرين ألفا: ستين ألف متبوع مع الرجل الثاكري, ومن الستين ألفا خمسة عثر ألف شريف منبوع.

45 Friedmann 1992, 53.

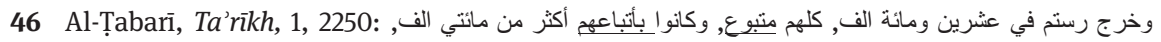
وخرج من المدائن في ستين ألف متبوع the translation is that of Friedmann 1992, 46. 
and the Shākiriyya:" وجاء رستم فنزل الحيرة في سنتين ألفا من المقاتلة سوى الأشياع والأتباع . ${ }^{47}$

Here, the Shākiriyya is mentioned not as part of the regular paid army but as one of the auxiliary units. ${ }^{48}$

\section{A/1.3) The Shākiriyya of Yazdajird: MC?/; S/NM?}

Ibn Tāhir relates in another tradition that several senior commanders were sent to Yazdajird by Sa'd b. Abī Waqqāṣ to persuade the king to recognize the superiority of Islam, demanding that he become a Muslim or "pay the jizya while

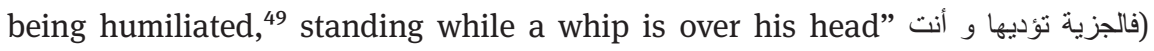
They were received by Yazdajird's son who responded: "If you were not messengers I would have killed you." So they answered: "We shall take your land and send you to exile from it." So he asked: "What is your proof (for this)?" and they said: "Our Prophet (șal'am) informed us about this, and there was nothing that he informed us about which did not materialize." Yazdajird's son (or is it the king himself?) said something in Persian to one of his Shākiriyya (فراطن بعض شاكريته) and he came quickly with a date-basket which contained dust of the earth, and he said: "Take this, this is what you'll get from me..." 50

This tradition is undoubtedly a topos, a literary convention, with many parallels in early Islamic sources on the conquests. Still, it was woven around some solid historical events, incorporating the names of real Arab commanders and places. Whoever spread this tradition was certain that the Sāsānian prince and/or king had a Shākiriyya. The nature of the Shākirī himself is not clear from this anecdote; he may have been a servant, or a soldier who belonged to a Shākiriyya military institution.

It is also noteworthy that this example is from a very early period, and that it deals with the Sāsānian (Persian) army in al-'Irāq; it does not touch on Central Asia.

47 Al-Maqdisī, al-Bad' wa-l-ta'rīkh, 5, 171.

48 For a different analysis and interpretation of this evidence, see De La Vaissière 2007, 73, who doubts the authenticity of this evidence (quoting only al-Maqdisī); and see the discussion above. 49 This is a paraphrase of the well-known Qur'ānic verse (9 (al-tawba):9), as well as an interpretation of this verse, which clearly attests to the later origin of the text.

50 Al-Maqdisī, al-Bad' wa-l-ta'rīkh, 5, 172. 


\section{B) The Umawī Period}

\section{B/1) al-'Irāq: $M C$}

The first time the Shäkiriyya is mentioned is in 77 H/696-697 CE, during the fierce battles between al-Ḥajjāj b. Yūsuf and Shabīb b. Yazīd al-Shaybānī alKhārijī in al-'Irāq (mainly near al-Kūfa). One of al-Hajajāj's notables and commanders, Khālid b. 'Attāb al-Riyāhī al-Tamīmīi, ${ }^{51}$ was sent from al-Kūfa at the head of his Shākiriyya ( $f \bar{\imath}$ Shākiriyyatihi) to fight Shabīb. The tradition was recorded by al-Ṭabarī from 'Umar b. Sahabba through Khallād b. Yazīd from al-Ḥajjāj b. Qutayba.52

\section{$B / 1.1) M C$}

Miskawayh relates that Khālid b. 'Attāb headed a company of soldiers of Ahl alKūfa together with his mawālī and his Shākiriyya. ${ }^{53}$

\section{B/1.2) MC}

Ibn Abī l-Ḥadīd relates that Khālid b. 'Attāb "came out with a group of his

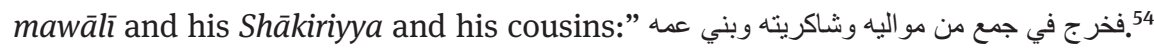

On the face of it, this is an exception to the geographic-social pattern established by some scholars, since its setting is not connected to the east (Khurāsān) and certainly not to Transoxania. Khālid b. 'Attāb was a Kūfī, who during his ca-

51 On Khālid b. 'Attāb, see Crone 1980, 112; al-Ziriklī 1980, 2: 297 (his entry); see also Ibn Ḥazm, Jamhara, 227; al-Balādhurī, Ansāb, 12, 161-162; Ibn 'Asākir, Ta'rīkh, 16, 172-175: his biography; 172: governor of al-Rayy; Ibn al-Kalbī, Jamhara (ed. H̦asan), 217 and al-Balādhurī, Ansāb, 12, 161: governor of Ișfahān after his father; al-Balādhurī, Ansāb, 7, 403: governor of al-Rayy; al'Askarī, Tașhīifāt, 2, 872.

52 Al-Ṭabarī, Ta'rīkh, 2, 965 (وجاء خالد بن عتاب في شاكريته; my emphasis); the isnād is on pp.963 and 964: 'Umar b. Sahabba < Khallād b. Yazīd< al-Hajajāj b. Qutayba [b. Muslim?]. In some of the traditions, 'ișāba (a company of soldiers) appears instead of the Shākiriyya (see al-Ṭabarī, Ta'rīkh, 2, 961; al-Dhahabī, Ta'rīkh, 5, 333), or jamā'a (Ibn Kathīr, al-Bidāya, 9, 24: a jamā'a of 4000 soldiers). See also the next footnote.

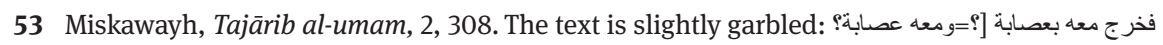
فخرج في عصابة؟] من أهل الكوفة مع مو اليه وشاكريته

54 Ibn Abī l-Ḥadīd, Sharh, 4, 271; Forand 1962, 10. His conclusions regarding this and other examples are farfetched. 
reer served as the governor of al-Rayy and Ișfahān in the Jibāl district (also far away from Transoxania). This was the heart of the Sāsānian kingdom. Did he recruit his Shākiriyya there?

Crone has already noted that at least two members of Khālid b. 'Attāb's subtribe (Riyāḥ b. Yarbū') were connected to Khurāsān. The first was Habīb b. Qurra [b. Nu'aym b. Qa'nab...b. Hammām b. Riyāh b. Yarbū'], who was the governor of Balkh in 29 H/649-650 CE on behalf of 'Uthmān..$^{55}$ But there is a chronological gap of about 50 years between Khālid b. 'Attāb's campaign and Hiabīb b. Qurra's governorship. The evidence in al-Ṭabarī (from 29 H/649-650 CE) is the only mention of Habìb b. Qurra in the sources. Nothing more is known of him, certainly not about any Shākiriyya contingents of his, nor is anything known about his relations with the family of Khālid b. 'Attāb.

The second person mentioned by Crone is al-Abrad b. Qurra b. Nu'aym, the brother of Habīb. ${ }^{56}$ His daughter was married to Yazīd b. Qurrā' al-Riyāḥī or alHanẓalī al-Tamīmī, who lived in Marw. ${ }^{57}$ As in the case of Habīb b. Qurra, no connection is recorded between Khālid b. 'Attāb and al-Abrad b. Qurra or between their families. It seems that the Khurāsānī background and connections of Khālid b. 'Attāb with these distant relatives and with the districts of Khurāsān and Transoxania need to be established on firmer ground. ${ }^{58}$

All the other pieces of evidence from the Umawi period (except two) are connected to Khurāsān and Transoxania.

55 Crone 1980, 113 (according to al-Tabarī, Ta'rīkh, 1, 2831).

56 On him, see Ibn al-Kalbī, Jamhara, 216; Ibn Ḥazm, Jamhara, 227; Ibn Mākūlā, al-Ikmāl, 1, 1011; he is only mentioned in these sources.

57 Crone 1980, 113 (according to al-Ṭabarī, Ta'rīkh, 2, 1569: al-Riyāhī); but see al-Ṭabarī, Ta’rīkh, 2, 1691: al-Hianz̧alī, a different sub-tribe of Tamīm.

58 De La Vaissière 2007, 72-73, note 193, mentions the evidence (according to al-Tabarî’s Ta'rìkh) about Khālid b. 'Attāb’s Shākiriyya in al-Kūfa (al-'Irāq), but argues, relying on Crone's observation, that "mais Crone 1980, p. 113, souligne les forts liens de sa famille avec le Khorassan (elle compte dans ses rangs un gouverneur de Balkh).” Crone’s assertion $(1980,113)$ about the Khurāsānī connection of Khālid and his father 'Attāb to Khurāsān is not attested to by the sources she quotes. Furthermore, she confuses 'Attāb and his son Khālid, mistakenly arguing that it was 'Attāb who had a Shākiriyya (quoting al-Ṭabarī, Ta'rīkh, 2, 950). 'Attāb’s different contingents are mentioned on this page, but no Shākiriyya contingents are listed. I am unable to trace any connection between 'Attāb and his son Khālid and Khurāsān. 


\section{B/2) Khurāsān: MC}

In 82 H/701-702 CE Thābit and Ḥurayth, the sons of Quṭba, mawālī of Khuzā'a and two commanders of the governor of Khurāsān al-Muhallab b. Abī Șufra, left al-Muhallab's camp with "three hundred of their Shākiriyya and their loyal and close Arab adherents." The isnād is as follows: al-Tabarī < 'Alī b. Muhammad al-Madā'inī (most probably from a written work) < al-Mufaḍdal b. Muhammad b. Ya' lā al-Ḍabbī (d. ca. 163 H/780 CE), ${ }^{59}$ whose "father was one of the authorities of al-Tabari on the events in the wars of the Arabs on the frontiers of Khurāsān in 30-90 H/651-709 CE.”60

\section{B/3) Transoxania: $M C$}

In $85 \mathrm{H} / 704-705 \mathrm{CE}$, Thābit and Hurayth, the two tribal leaders and commanders mentioned above, found a refuge in Tirmidh (in Transoxania, on the Oxus river) dominated by Mūsā b. 'Abdallāh b. Khāzim al-Sulamī. ${ }^{61}$ At a certain stage Thābit turned against Mūsā and with the help of the princes of Transoxania fought against him. Thābit had to guard against assassination and ordered a group of his Shäkiriyya "to guard him, to sleep in his house at night, and with them, a group of Arabs (ومعهم قوم من العرب)".62

Barthold argued for the Iranian origin of this personal guard (Shākiriyya), but no indication of this guard's ethnicity is included in the source he quoted. He further argued that the phrase "and with them, a group of Arab tribes" means Thābit's enemies in the camp of the leader of Khuzā'a. The text is not as clear-cut as Barthold deems, and it is definitely possible to assume that the Shākiriyya that appears in this text also included Arabs. ${ }^{63}$

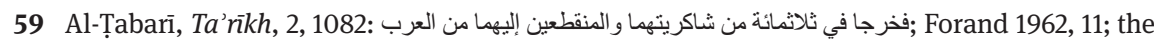
expression والمنقطعين is rendered by Hinds 1990 as: "three hundred of their shākiriyya and Arab adherents [my emphasis]" and by De La Vaissière 2007, 71 as "et leur suivants arabes [my emphasis]."

60 Lichtenstädter, “al-Mufaḍḍal b. Muḥammad....al-Ḍabbī,” $E I^{2}$, 7, 305-306.

61 On Mūsā b. 'Abdallāh b. Khāzim al-Sulamī, see al-Ṭabarī, Ta'rīkh, 2, index, esp. 1145ff.; Shaban 1979, index, esp. 58-49, 58-62; on al- Thābit and Ḥurayth, see al-Ṭabarī, Ta'rīkh, 2, index, esp. 1145ff.; Shaban 1979, index, esp. 57-61.

62 Al-Ṭabarī, Ta’rīkh, 2, 1155; وأمر قوما من شاكريته يحرسونه ويبيتون عنده في داره ومعهم قوم من العرب; Barthold 1928, 183; De La Vaissière 2007, 71, note 181.

63 Barthold 1928, 183; Hinds 1990, 99: "they being accompanied by some Arabs.” 


\section{B/4) Transoxania: SE/NM}

The Shākiriyya of Tarkhūn, the king of Samarqand and ruler of Soghdia, is mentioned in the year $85 \mathrm{H} / 704-705 \mathrm{CE}$. He is in a military camp, leading a coalition of non-Arabs and Arabs against Mūsā b. 'Abdallāh b. Khāzim al-Sulamī, who has gained control over Tirmidh. Țarkhūn is described sitting in his tent, "and his Shākiriyya had lit fires before him." They scattered when they heard the voice of one single enemy soldier who entered the tent and is killed by Tarkhūn. Then the Shākiriyya returned and Țarkhūn scolded them, saying "You fled from a [single] man." Then his slave girls entered the tent and the Shäkiriyya fled.

It seems that the Shäkiriyya in this case are servants, not soldiers; certainly not courageous warriors since they did not even try to resist their lord's attacker. ${ }^{64}$ The isnād is as follows: al-Ṭabarī < 'Alī b. Muhammad [al-Madā'inī]. ${ }^{65}$ It is unsound to conclude from this text, as Forand did, that "the Shākiriyya of the Iranian rulers must have been slaves." 66

\section{B/5) Jurjān/Khurāsān: NM/SE?}

In $98 \mathrm{H} / 716-717 \mathrm{CE}$, in the course of Yazīd b. al-Muhallab's long siege of Jurjān (located southeast of the Caspian Sea), "a non-'Arab (soldier?) from Khurāsānwho was with Yazīd-went out to hunt with a Shākiriyya of his.” While chasing a wild mountain goat (antelope?: وعل), he discovers a small path in the mountains leading to the besieged fortress. This evidence is connected to the east via Khurāsān (but not Transoxania); the identity of the "hunter" is not clear. Was he a commander or an Iranian notable? The isnād is as follows: al-Tabarī < 'Alī b. Muhammad [al-Madā'inī] < "the group that transmitted to him the report about Jurjān and Ṭabaristān.” 67

Al-Tabarī records two additional conflicting versions (see below) of the identity of this soldier or commander who discovers the secret pass to the besieged city while hunting. In these versions, the "heroes of the anecdote" are Arabs.

64 Cf. De La Vaissière 2007, 71: "ils veillent sur sa tente mais ne résistent pas à une attaque." 65 Al-Ṭabarī, Ta'rīkh, 2, 1159-1160; the beginning of the long tradition (mention of al-Madā'inī) is on 1146; Barthold 1928, 180; Forand 1962, 10; De La Vaissière, 2007, 71, note 182 (quoting alȚabarī).

66 Forand 1962, 11.

67 Al-Ṭabarī, Ta’rīkh, 2, 1330-1331: إذخ جر رجل من عجم خر اسان كان مع يزيد ينصيد ومعه شاكرية له is is it possible that the phrase شاكرية له denotes a female Shākir? 


\section{B/5.1)}

The second version of this story is related by Hishām b. Muhammad al-Kalbī (d. 204 H/819 CE) from Abū Mikhnaf (d. 157 H/774 CE), who reports that the "hunter" was an Arab soldier from the Tayyi’ tribe (رجل من عسكره من طيّ). He is accompanied by a group defined as $a s ̣ h \bar{a} b$, which may denote close associates and in this case most probably means close commanders or soldiers who were attached to him or were part of the contingents he commanded. ${ }^{68}$ The term Shäkiriyya/ shäkiriyyatihi is not mentioned in this tradition or in the next version.

\section{B/5.2)}

The third version is recorded by al-Tabarī, who does not name his source and uses the term "and it is said" (ويقال). It may have originally been part of Ibn alKalbī's tradition. This third version says that the hunter's name was al-Hayyāj b. 'Abd al-Raḥmān al-Azdī, from the (Arab?) inhabitants or warriors of Ṭūs (الهياج بن عبد الرحمن الأزدي من أهل الطوس). According to this version, he came out from Yazīd's camp for the purpose of hunting. ${ }^{69}$

\section{B/5.3)}

Ibn A'tham al-Kūfī records only the last, third version of this anecdote and weaves it around al-Hayyāj b. 'Abd al-Raḥmān al-Azdī. No sources are recorded, but it is most probably taken from al-Madā'inī's work. This is a long and detailed tradition, describing how during the prolonged siege of the fortress by Yazīd $b$. al-Muhallab, "one of his close associates/commanders, from the (Arab?) contingents of al-Ṭūs, named al-Hayyāj b. 'Abd al-Raḥmān al-Azdī went out hunting with a dog... and there were with him a group [of soldiers] from the army camp..."

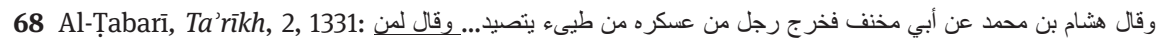

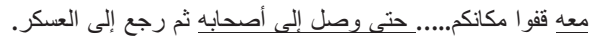

69 Al-Ṭabarī, Ta'rīkh, 2, 1331.

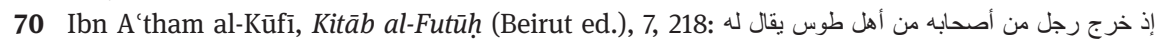
الهياج بن عبد الرحمن الأزدي إلى الصيد ومعه كلب.....وقد كان معه قوم من العكر (my emphasis]; al-Madā'inī is mentioned in Ibn A'tham al-Kūfî, Kitāb al-Futūh (Beirut ed.), 7, 206. Ibn A'tham relied heavily on alMadā'inī’s works; see Conrad 2015, 99, n. 77, 115-116, 118, 125; Lindstedt 2014, esp. 107-108, 110, 117. 
It is clear that we are again faced with a topos, but some elements of the anecdote may have a grain of authenticity. ${ }^{71}$ It is interesting (and may be of importance) that the Shäkiriyya is mentioned in connection with an Iranian. The two other Arab commanders are not connected to a Shākiriyya.

Again, it is worth reminding ourselves that the term al-Shākiriyya was a common, well-known term in the mid $-9^{\text {th }}$ century when al-Madā'inī lived and worked.

\section{B/6) Syria/Dābiq. Between 96 H/715 CE and 99 H/717 CE, the Reign of Sulaymān b. 'Abd al-Malik: NM/SE?}

Yāqūt quotes an anecdote that he most plausibly copied from Akhbār al-Nahawiyyīn (The History of the Grammarians), ${ }^{72}$ a book by Muhammad b. 'Abd alMalik, Abū Bakr al-Sarrāj, known as al-Ta'rīkhī (d. 291 H/903-904 CE) ${ }^{73}$ : “And he related in the tradition whose isnād concludes with al-Ḍaḥāk b. Ziml/ Zaml al-Saksakī, who was one of the close associates of al-Manșūr وكان (وك) )

We were together with Sulaymān b. 'Abd al-Malik [r. 96/715-99/717] in Dābiq, ${ }^{75}$ when alShaḥhāj [b. Wadā'] al-Azdī al-Mawșilīi ${ }^{76}$ rose up in his presence and said [in incorrect Ara-

71 Cf. the summary of al-Madā'inī's tradition in al-Balādhurī, Futūḥ (Beirut, 1987), 471: "[Yazīd] laid siege to the fortress for seven months, with no apparent results, then a man (a soldier?) diفنزل عليها سبعة أشهر لا يقدر منها شيء...ثم إن رجلا : فلهم على طريق إلى قلعتهم 183 (according to al-Ṭabarī, Ta’rīkh, 2, 1331), refers only to one man, "un Iranien de Țūs." This combines the two versions and two different commanders rendered by al-Ṭabarī.

72 Yāqūt, $U d a b \bar{a}$, 1, 27. Yãqūt copied the traditions from the book that was before him, see 1, 5 and 13; 2, 551:ونقلت في كتاب محمد بن عبد الملك التأريخي في أخبار النحويين قال :al...; this book was already mentioned by Ibn al-Nadīm, al-Fihrist, 95; al-Ṣafadī, al-Wāfī, 46: كتاب تأريخ النحويين; see also GAL, S3, 157. It is not mentioned by Sezgin.

73 On him, see al-Khatị̂b al-Baghdādī, Ta'rīkh, 3, 151; 11, 69: al-Khatị̂b al-Baghdādī used an autograph of the author (quoted by Ibn 'Asākir, Ta'rīkh, 59, 254): قرأت في كتاب محمد بن عبد الملك التأريخي بخطه; al-Sam 'ānī, al-Ansāb, 1, 442; Yāqūt, Udabā' , 1, 5-6; al-Dhahabī, Ta'rīkh, 23, 278-279, who does not give the exact date of his death; al-Șafadī, al-Wāfì, 4, 35; al-Ṭihrānī, al-Dharī $a$, 21, 28 quotes Yāqūt and gives birth and death dates (200 H/815-816 CE to 291 H/903-904 CE).

74 For this social-political institution within the early 'Abbāsī court, see Elad 1995, 93, n. 17; alDaḥ̣āk should be added to the list of the șahāba of al-Manșūr: وكان من أصحاب المنصور.

75 "A locality in the 'Azāz region of northern Syria. It lies on the road from Manbij to Anțākiya upstream from Aleppo on the river Nahr Kuwayk." Sourdel , "Dābik," $E I^{2}, 2$, 72; see also Le Strange 1890, 426.

76 For more on him, see below. 
bic, not according to the rules of the Arabic grammar]: 'Oh Commander of the Faithful, Our father has died and left a large sum of money but our brother took control of our father's money and took it...' Upon hearing the incorrect Arabic the caliph became very angry and addressed the speaker with harsh bold words and added 'Take this man who speaks incorrect Arabic from me.' So one of the Shākiriyya took his hand saying [also in incorrect Arabic]: 'Get up for you have offended the Commander of the Faithful.' Hearing the incorrect, faulty Arabic, the caliph cursed the Shākiri and ordered to drag him away by his legs. ${ }^{77}$

Yāqūt records only the last transmitter of the tradition, al-Ḍaḥāk b. Ziml/Zaml b. 'Amr al-Saksakī (Kinda), a well-known Umawī Arab notable who lived in Bayt Lihyā, one of the villages of Damascus. ${ }^{78}$ His father was one of the closest and most senior associates of caliph Marwān b. al-Ḥakam (r. 64 H/684 CE-65 H/ $685 \mathrm{CE}$ ). He was also a minor transmitter of ḥadìth. ${ }^{79}$ His son, al-Ḍaḥhāk b. Zamal/Ziml related traditions about Sulaymān b. 'Abd al-Malik; in another tradition he gives an eyewitness description of the audience of caliph Yazìd $b$. 'Abd al-Malik (r. $101 \mathrm{H} / 720 \mathrm{CE}-105 \mathrm{H} / 724 \mathrm{CE}){ }^{80}$ He was appointed by caliph al-Walīd b. Yazīd b. 'Abd al-Malik (r. 125 H/743 CE-126 H/744 CE) as the governor of al-Yaman. ${ }^{81}$ Yazīd b. al-Walīd (r. 126 H/744 CE) confirmed his appointment as the governor of al-Yaman and Haḍramawt where he remained as governor under Marwān b. Muhammad (r. 126 H/744 CE-132 H/750 CE) for two years and a few months. ${ }^{82}$ His brother al-Ḥajjāj b. Ziml accompanied Marwān b. Muhammad on his flight to Egypt and was killed with him in Būṣīr. ${ }^{83}$ Yāqūt adds an interesting and otherwise unknown fact about him: that he continued to serve the 'Abbāsī caliphs as well and was one of the șahāba of caliph al-Manșūr.

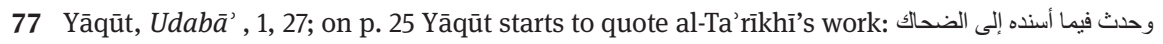

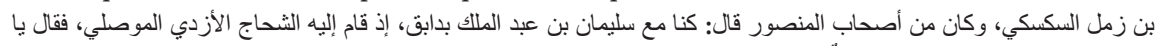

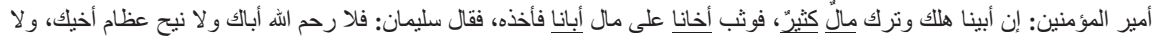

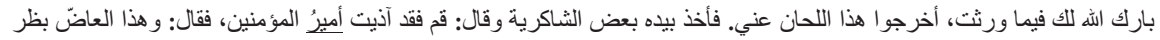
أمه اسحبوا برجله Maymanī, Simt al-la'ālī, 66, explaining that the meaning of the word Shākiriyya is al-khadam (servants/eunuchs?) and it is derived from Persian: خدم, فارسية .

78 On him see Ibn 'Asākir, Ta'rīkh, 24, 263-266; Ibn Khayyāț, Ta'rīkh, 2, 384, 432; Ibn Abī Ḥātim, al-Jarh, 4, 461; Ibn Ḥajar, al-Ișāba, 4, 96.

79 On him, see Ibn 'Asākir, Ta'rīkh, 19, 79: وكان من وجوه أصحاب مروان بن الحكم.

80 Ibn 'Asākir, Ta'rīkh, 24, 264: on Sulaymān b. 'Abd al-Malik; 265: in the presence of Yazīd (= al-Azdī, Ta'rīkh al-Mawșil, 15: called Ibn Ramal instead of Ziml/Zaml); on the lineage of the family, see Ibn al-Kalbī, Nasab Ma'add, 1, 195.

81 Ibn Khayyāt, Ta'rīkh, 2, 384.

82 Ibn 'Asākir, Ta'rīkh, 24, 265; see also Ibn Khayyāț, Ta'rīkh, 2, 432.

83 Al-Azdī, Ta'rīkh al-Mawșil, 136-137: related by his brother al-Ḍaḥhāk to al-Haytham b. 'Adī; Crone 1980, 104. 
Very little is known of al-Shaḥhāj b. Wadā' al-Azdī al-Mawșilī, who went from al-Mawșil to Sulaymān b. 'Abd al-Malik in Dābiq. ${ }^{84}$ In the year 101 H/719-720 CE, he was sent by caliph Yazīd b. 'Abd al-Malik at the head of a force of 2,000 men to fight the Khawārij near al-Kūfa. There he was killed by the Khārijites. ${ }^{85}$

\section{B/6.1)}

A parallel tradition recorded by Ibn 'Asākir gives us the complete isnād. It was related by al-Dahḥāk b. Ziml/Zaml to the famous scholar al-Haytham b. 'Adi (d. $207 \mathrm{H} / 822 \mathrm{CE}$ ). The name of al-Shaḥhāj b. Wadā' is not mentioned. Instead an anonymous man (rajul) is mentioned: “....al-Haytham [b. 'Adī]: It was related to me (haddathanī) by al-Ḍaḥhāk b. Ziml who said: 'I witnessed Sulaymān b. 'Abd al-Malik when he was checking (reviewing) horses in Dābiq when a man rose up to him and said ... [the same corrupted Arabic sentences about his father and brother; then the angry answer (curse) of the caliph is mentioned and instead of the Shākirī, the caliph calls to his slave (غلام)] : 'Oh slave, bring the whip (or: whip him)'."86

\section{B/6.2)}

A parallel tradition is recorded by al-Marzubānī. The only word that is omitted is "the slave" (al-ghulām). ${ }^{87}$

84 Ibn 'Asākir, Ta'rīkh, 20, 142 [= Ibn al-'Adīm, Bughya, 9, 4187]: Saḥhāj instead of Shaḥhāj. 85 Al-Ṭabarī, Ta'rīkh, 2, 1376 is the only source that mentions his father Waḍā'; see also al-Azdī, Ta'rīkh al-Mawșil, 7.

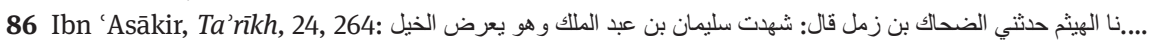

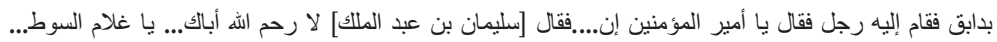

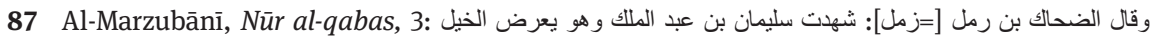

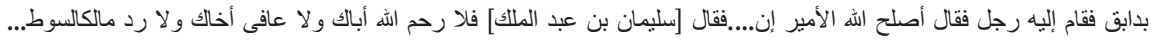




\section{B/6.3)}

A partially parallel tradition (again, not mentioning the Shākirī/ghulām) was related by al-Ḍaḥhāk b. Ziml to another famous scholar, 'Abdallāh b. al-Mubārak (118 or $119 \mathrm{H} / 736$ or $738 \mathrm{CE}-181 \mathrm{H} / 797 \mathrm{CE}){ }^{88}$

\section{A Short Analysis of this Tradition}

The impression one gets from reading this tradition is that it has some grain of authenticity. It was related by well-known notables and scholars (that is, real historical figures). The last link is an Umawī/ 'Abbāsī notable, who was the associate of both Umawī and 'Abbāsī caliphs and himself an eyewitness to the event. It is of importance that al-Haytham b. 'Adī and 'Abdallāh b. al-Mubārak, two completely different famous scholars from different regions of the Islamic world, both reported this tradition from al-Dahḥāk b. Ziml.

Both al-Ḍaḥhāk b. Ziml (the last transmitter) and al-Shaḥhāj b. Wadā‘ alMawṣilī were contemporaries of Sulaymān b. 'Abd al-Malik; al-Shaḥhāj came to him to Dābiq, where this caliph lived for several years, and died there. ${ }^{89}$

However, some of the main features of the tradition were related about an anonymous man (رجل), who appears before Ziyād b. Abī Sufyān, the governor of al-'Irāq (d. 53 H/672-673 CE), complaining in incorrect Arabic that his brother had seized his father's inheritance. Upon hearing his Arabic, Ziyād scolds and/or curses him. No ghulām/shākirī is mentioned. No isnād is attached to this version of the tradition; no names beside that of Ziyād are mentioned, and nor is any geographical background or name. We are facing a stereotypical literary form or topos. It is similar to other examples of this kind found in special chapters in the $a d a b$ literature dealing with anecdotes about the laḥhānūn (those who spoke incorrect Arabic). ${ }^{90}$

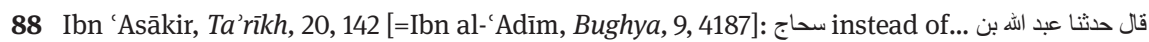

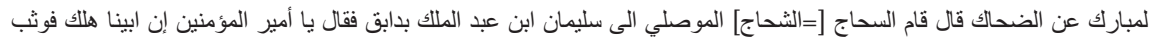

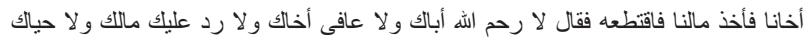

89 Eisener, "Sulaymān b. 'Abd al-Malik," $E I^{2}$, 9, 821-822.

90 For the tradition about Ziyād b. Abī Sufyān and the man who was cheated by his brother,

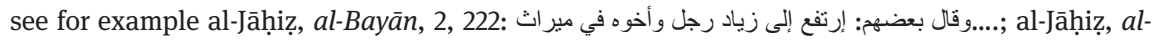

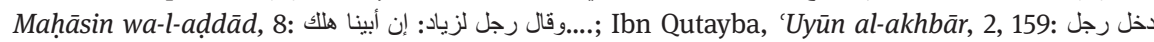

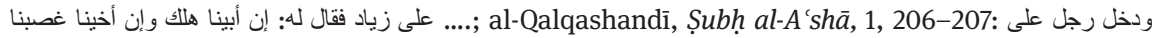
زياد بن أبيه فقال إن أبونا مات و إن أخينا وثب على مال أبانا فأكله فقال زياد للأي أضعته من كلامك أضر عليك مما أضعته من مالك الك. 
This last section has taken me beyond my field of expertise. My aim is to understand the social-military meaning of the Shākiriyya institution in the early Islamic period, and I am afraid that this long discussion has brought me to a dead end. Reading version A of the tradition gives the sound impression that it is authentic. But after reading the second version (where Ziyād b. Abīhi is the main figure instead of Sulaymān b. 'Abd al-Malik), that seems less clear. All that can be safely said is that the word was used in the middle of the $8^{\text {th }}$ century, and in this specific tradition about Sulaymān b. 'Abd al-Malik and al-Shaḥ̣āj b. Wadā' it can denote a servant or a slave. In this case I prefer this meaning to a military interpretation.

\section{B/7) Transoxania; Soghdia: MC}

In 104 H/722-723 CE, the governor of Khurāsān Sa'īd b. 'Amr al-Ḥarashī led the campaigns against Soghdia. Al-Ṭabarī reports the events of the conquest (as in most of the traditions relating the history of Khurāsān during the Umawī period) from the book[?] of Abū l-Ḥasan al-Madā'inī (d. ca. 225 H/840 CE) from his authorities (așhābihi). Al-Harashī’s army conquers the city of Khujanda. ${ }^{91}$ After the city's surrender, one of the Soghdian senior commanders, Kārzanj, sends a message to his nephew that al-Harashī is plotting to kill the Soghdian noble commanders; therefore the nephew "took out pieces of green silk cloth, cut it into strips and tied the strips around the heads of his Shäkiriyya, then he came out, he and his Shäkiriyya and attacked the (Umawī soldiers) and killed some." The isnād is al-Ṭabarī < 'Alī [b. Muhammad al-Madā'inī] < from his authorities ('an aṣhāabihi). ${ }^{92}$

\section{B/8) Khurāsān; Transoxania: MC}

In the year $111 \mathrm{H} / 729-730 \mathrm{CE}$ during Hishām b. 'Abd al-Malik's reign, two army commanders, 'Āṣim b. 'Umayr al-Ṣuraymī, al-Samarqandī, and Wāṣil b. 'Amr alQaysī, are mentioned as having fought the Turks in Transoxania and commanding a Shākiriyya with whom they attacked the enemy. The isnād is as follows: al-

91 On the city, see Bosworth, "Khudjand(a)", $E I^{2}$, 5, 45-46.

92 Al-Ṭabarī, Ta'rīkh, 2, 1445: أخرج فرندة خضر اء فقطعها عصائب و عصبها برؤوس شاكريته ثم خرج هو وشاكريته فاعترض الناس فقتل ناسا the green colour had any significance in Transoxania/Soghdia; noteworthy is that al-Ma'mūn changed the colour of the 'Abbāsīs from black to green. 
Ṭabarī < 'Alī b. Muḥammad [al-Madā'inī] < Abū l-Dhayyāl [Zuhayr b. Hunayd al'Adawī]. ${ }^{93}$ We do not know anything about the ethnic character of the soldiers of this Shākiriyya.

Abū l-Dhayyāl al-Zuhayr b. Hunayd was one of al-Madā'inī’s main informers about the battles of the Muslims in Khurāsān (especially in Transoxania) during the Umawī period, mainly during the reign of Sulaymān b. 'Abd al-Malik (r. 96 H/ 715 CE-99 H/717 CE). Abū l-Dhayyāl most plausibly had a work about the Muslim conquests of Transoxania. In that case the information in it was related to him by members of his family, either by his uncle al-Muhallab b. Iyās, or perhaps directly by his grandfather Iyās b. Zuhayr b. Hiayyān b. Qamī’a, or by the latter's two brothers 'Ubaydallāh and 'Abdallāh, commanders of the Arab forces in Transoxania in $96 \mathrm{H} / 714-715$ CE during the governorship of Qutayba b. Muslim ${ }^{94}$ and probably later on as well. Iyās' father Zuhayr b. Ḥayyān and Iyās himself were in Khurāsān already in 65 H/684-685 CE and are mentioned among the Arab commanders in Khurāsān who took part in the tribal war in the province following the death of Yazīd b. Mu'āwiya. ${ }^{95}$ Zuhayr b. Hayyān was the leader of Banū 'Adī (Quraysh) and carried the clan's flag in battle. ${ }^{96}$

\section{B/9) Khurāsān; Transoxania: MC/?}

In the year $112 \mathrm{H} / 730-731 \mathrm{CE}$, within the framework of the battles of the governor of Khurāsān al-Junayd b. 'Abd al-Raḥmān in Transoxania, al-Ṭabarī reports from the book[?] of Abū al-Ḥasan al-Madā'inī from Abū l-Dhayyāl [Zuhayr b. al-Hunayd al-'Adawì (on him see the preceding note)], that in one of the battles (of

93 Al-Ṭabarī, Ta’rīkh, 2, 1528: فخرج عاصم بن عمير السمرقندي وواصل بن عمرو القيسي في شاكرية; mentioned by De La Vaissière 2007, 71, note 185; cf. al-Ṭabarī, Ta'rīkh, 2, 1528, note n, according to ms. BM: وحمل واصل و الثاكرية :شاكريته : شاكرية instead al-Ṭabarī, Ta'rīkh, 2, 1528, lines 12-13 ساكريته على العدو

94 Naqā'iḍ Jarīr wa-Farazdaq, I, p. 357 (cited by Blankinship 1989, p. 42, note 189): correct Blankinship 1989, p. 42, note 189, “al-Hunayd b. Iyās” to "Zuhayr b. Hunayd”; al-Ṭabarī records dozens of his traditions via 'Alī b. Muhammad al-Madā’inī. Abū l-Dhayyāl, Zuhayr b. Hunayd was also a minor muhaddith, for example, see Ibn Hajar, Tahdhīb, 3, 305 and al-Mizzī, Tahdhīb, 9, 428. Is Abū l-Dhayyāl, a rāwī of Khalīfa b. Khayyāț, relating traditions about the battles of Abū Muslim in Khurāsān in 129 H/746-747 CE, and also about the battles between Marwān b. Muhammad and the 'Abbāsīs in 132 H/750 CE, Abū l-Dhayyāl al-'Adawī? See Ibn Khayyāt, Ta'rīkh (index). Ibn al-Athīr, al-Kämil, 5, 370, informs us of a commander of the governor of Khurāsān (Nașr b. Sayyār) named Abū l-Dhayyāl fighting against the forces of Abū Muslim. 95 Al-Ṭabarī, Ta'rīkh, 2, 495, ll. 7ff.

96 Al-Tabarī, Ta'rīkh, 2, 490; 495: carrying the flag of Adì. 
that year), the Muslim army was defeated. One of the Muslim commanders received a safe-conduct from Ghūrak, a Turkish prince of Samarqand, but the Khāqān of the Turks did not approve of the safe-conduct and Ghūrak consequently apologized to the Arab commander for its withdrawal saying: "I am a slave of the Khāqān, from his Shākiriyya."97

Beckwith concludes from this passage that:

...the relationship between lord and chākar was extremely close indeed; al-Iskand's ally Ghūrak, the king of Samarkand, speaks of his feudal relationship to his Western-Turkic liege-lord...It appears therefore that the members of the central Asian guard corps spoke of themselves as the slaves of their lord. [my emphasis]

De La Vaissière also stresses the importance of this text:

C'est un texte important. Il ne s'agit pas là d'une simple alliance militaire: le roi de Sogdiane se définit comme le subordonné du qaghan dans la stricte continuité de l'histoire longue de l'Asie centrale. Un siècle et demi après Maniakh, c'est bien sur la longue durée que sont établis les liens politiques entre qaghans turcs et princes sogdiens. ${ }^{98}$

Again, we need more than one (equivocal) piece of evidence to corroborate this social-cultural and ethnic institution.

\section{B/10) Transoxania: $M C /$ ?}

In $119 \mathrm{H} / 737 \mathrm{CE}$, in one of the battles in Transoxania between the Khāqān of the Turks (who was aided by al-Ḥārith b. Surayj al-Tamīmī) ${ }^{99}$ and Asad b. 'Abdallāh al-Qasrī, the governor of Khurāsān, "the Khāqān drew support from Transoxania, the inhabitants of Ṭukhāristān and Jīghawayh [read Jabghūyah?] al-Ṭukhārī, along with their kings and their Shākiriyya, to the number of thirty thousand.”100

97 Al-Ṭabarī, Ta'rīkh, 2, 1542: أنا عبد لخاقان من شاكريته [my emphasis]; see also the discussion of Lee Yonggyu above.

98 De La Vaissière 2007, 96; ibid., 72 and 96: “Je suis l'esclave du Khāqān de sa shākiriyya: reading الخخاقان instead of لخاقان.

99 On him, see Kister, "al-Ḥārith b. Surayj," $E I^{2}$, 3, 223-224.

100 Al-Ṭabarī, Ta'rīkh, 2, 1604 (after the translation of Blankinship 1989, 140): no specific

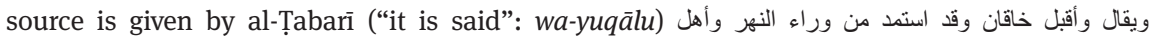
mentioned by Forand 1962, 10, and translated by De La Vaissière 2007, 72, note 188. 


\section{B/11) Transoxania. The Same Year, 119 H/737 CE: MC}

Within the same framework of the battles of Asad b. 'Abdallāh, who appointed al-Qāsim b. Bukhayt al-Maghārī al-Azdī in charge of the overall order of the army. "He put the Azd, the Banū Tamīm and al-Juzjān b. al-Juzjān and his Shākiriyya on the right wing." The transmitter, 'Amr b. Mūsā, is not otherwise identified. ${ }^{101}$

\section{B/12) Transoxania (al-Khuttal). The Same Year, 119 H/737 CE, Once Again within the Framework of the Battles of Asad b. 'Abdallāh in Transoxania: SE/SL? NM?}

Asad led an army against al-Khuttal, conquered the city, captured its king and executed him. It is related that during the battles, Asad "came upon a river, while thirsty-with none of his servants around, he asked for water." One of his commanders, al-Sughdī b. 'Abd al-Raḥmān, Abū Ṭu'ma al-Jarmī, had with him a Shākirī, who had with him a Tibetan horn; so al-Sughdī took the horn, put sawi $\mathrm{q}^{102}$ in it, and then poured water from the river on it, turned it and gave the drink to Asad and a small number of the senior commanders of the army. ${ }^{103}$ There is no indication that this Shākiri was a soldier; he may have been a servant.

101 Al-Ṭabarī, Ta'rīkh, 2, 1609: فجعل الأزد وبني تميم والجوزجان بن الجوزجان وشاكريته ميمنته ibid., note i, in ms. B: ميمنة; the name of the transmitter is on 1608, 1. 16; mentioned by Forand 1962, 11, and De La Vaissière 2007, 72.

102 Blankinship 1989, 163: "parched barley;" for the meaning of the term, see Waines, "Sawik," $E I^{2}, 9,93$.

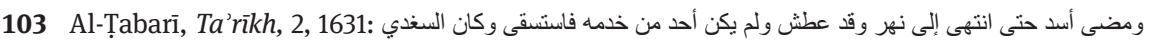

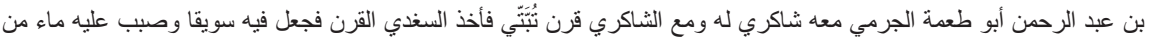
النهر وحركه وسقى أسدا وقوما من رؤساء الجند :Beckwith 1984, 37, note 40 (correct: 1637 to 1631); De la Vaissière 2007, 72; Beckwith 1984, 37, speaks about al-Iskand, "the displaced king of Kish and Nasaf...against whom the Arabs-including Nașr b. Sayyār-had fought for nearly a decade. Al-Iskand was known to the Chinese as the "King of the Chākars." [quoting Wang Ch'in-jo, et al., ed. Li Ssu-ching, Ts'e fu yüan kuei, i-xx, Taipei, 1972]. “...in 737 Nașr was with Asad in the so-called Battle of the Baggage [quoting al-Ṭabarī, Ta'rīkh, 2, 1597] against the Qaghan of the Turkish who had al-Iskand...with his chākars and their allies.” And on p. 38, Beckwith speaks again of al-Iskand and his chākars (quoting al-Tabarī, Ta'rīkh, 2, 1717-1718); I was unable to find al-Iskand's chākars (Shākiriyya) in al-Ṭabarī, Ta'rīkh, 2, 1597, or 1717-1718, or in any other page of this work. 


\section{B/13) Secretary/ Transoxania; Farghāna: NM}

In 121 H/739 CE, Nașr b. Sayyār, the governor of Khurāsān, sent Sulaymān b. Ṣūl to the ruler of Farghāna with the written pact of reconciliation between them (بكتاب الصلح بينهما). When Sulaymān reached the ruler's court, the latter asked him, "Who are you?” Sulaymān answered: “a Shākirī, the deputy of the (chief) secretary of the governor (شاكري, خليفة كاتب الأمبر ).”104 Who is this Sulaymān b. Șūl? This is the only source that mentions him. It is highly plausible that this Shākirìs father was the ancestor of the famous family of scholars and notables known by the nickname al-Ṣūlì. Șūl was of Turkish origin, the ruler of Dihistān (near Jurjān) and then for a short time the lord of Jurjān, who (according to one version) was converted to Islam by Yazìd b. al-Muhallab when he conquered Jurjān in 98 H/716-717 CE. According to family tradition, though, Yazīd b. al-Muhallab sent him to become a Muslim at the hands of Sulaymān b. 'Abd al-Malik, and he was sent by the latter to al-Madina where he converted to Islām. ${ }^{105}$ Many of his descendants are known to have had flourishing careers under the early 'Abbāsīs. His son, Muhammad b. Șūl, was one of the $70 d u$ 'āt of the 'Abbāsī "Revolution."106 If our assumption is correct, an unknown son of Șūl worked as a secretary at Nașr b. Sayyār's court in Marw. In any case, he defines himself as a "Shākiri, the deputy of the (chief) secretary of the governor." In this case, the meaning of the term does not seem to be connected to military service.

104 Al-Ṭabarī, Ta'rīkh, 2, 1695; Ibn al-Athīr, al-Kāmil, 4, 449; cf. De La Vaissière 2007, 72: "Je suis shākir et l'envoyé secrétaire de l'émir." ("I am a shākirī, the messenger, secretary of the Amīr.") 105 The first version: al-Khațīb al-Baghdādī, Ta'rīkh, 6, 115; Ibn Khallikān, Wafayāt, 1, 45; the second version: al-Sahmī, Ta'rīkh Jurjān, 236; the tradition is recorded from the Ta'rikh of al-Sal [1?]āmī (that is, Abū 'Alī al-Ḥusayn b. Aḥmad al-Bayhaqī al-Sallāmīi lived around 350/961); his book was entitled كتاب التاريخ في أخبار و لاة خر اسان usually mentioned as كتاب التأريخ. On him, see Sezgin 1967, 1: 352 (rendering his name as al-Salāmī); and esp. Rosenthal 1968, 321-322 and n. 7 (al-Sallāmī); for quotation from al-Sallāmī’s book, see for example, Ibn Khallikān, Wafayāt, 2, 521[= alȘafadī, al-Wāfī, 16, 228]: قال السلامي في أخبار ولاة خر اسان

106 On the family and some of the its most important members, see Leder, "al-Ṣūlī," $E I^{2}, 9$, 846-848. On Muhammad b. Șūl, one of the 70 du'āt, see Akhbār al- 'Abbās, index; al-Ṭabarī, index. Șūl died in the "battle of al-'Aqr," that is, 'Aqr Bābil near Karbalā', al-'Irāq, at the side of his master Yazīd b. al-Muhallab who rebelled against Yazīd II in 101 H/720 CE. See Ibn Khallikān, Wafāyāt, 1, 45-46; al-Khațīb al-Baghdādī, Ta'rīkh, 6, 115; for detailed accounts of the revolt and battles, see al-Ṭabarī, Ta'rīkh, II, $1395 f f$ (Șūl is not mentioned though); Shaban 1976, 93-95; Crone 1980, 133; Hawting 2000, 75-76. 


\section{B/14) Khurāsān; Marw: MC? NM?}

In the year $121 \mathrm{H} / 738-739 \mathrm{CE}$ the noted 'Āṣim b. 'Umayr (no. 8) served as commander of the army of the people[?] of Samarqand. ${ }^{107}$ In the year $128 \mathrm{H} /$ 745-746 CE he came (from Samarqand?) to Nașr b. Sayyār, the governor of Khurāsān, and joined him along with additional Arab forces in his battle against Abū Muslim and his armies. ${ }^{108}$ In the year 131 H/748-749 CE 'Āṣim was captured and executed by Abū Muslim. The tradition tells that while yet captive and before he was killed, a Shākirī that he had in Khurāsān recognized him and ordered his slave [? ghulām] to hide him in a subterranean place (a conduit by which water enters?:sarab), and not to disclose this hiding place to anyone. ${ }^{109} \mathrm{I}$ do not know if what is meant is a servant or a soldier of the Shākiriyya army with whom he fought in Transoxania. It is noteworthy that this Shākirī owned a slave. Perhaps he was well-to-do and of noble Iranian (Turkish?) descent. Wellhausen, who most probably had before him a large part of the sources (though he does not cite them) explains that:

...following the example of the distinguished Iranians, the Arab gentlemen took with them into the field a personal following of servants (Shākiriyya). These servants also took part in the fighting and sometimes decided the struggle. ${ }^{110}$

\section{B/15) Khurāsān; Marw: MC}

In the year $128 \mathrm{H} / 745-746 \mathrm{CE}$, during the fierce tribal wars in Khurāsān between the coalition of governor Nașr b. Sayyār's Muḍarī (Qaysī) and the Azd and Rabī'a led by Juday' b. 'Alī al-Kirmānī al-Azdī, the governor's forces in Marw were on the verge of defeat. "Tamīm b. Nașr b. Sayyār, sent his Shākiriyya, who were stationed[?] in the Dār of Janūb bt. al-Qa'qā' [b. al-A'lam al-Azdī], but the soldiers of al-Kirmānī shot at them from the roofs, so they (the Shākiriyya) knew of the

107 Al-Ṭabarī, Ta'rīkh, 2, 1690: وهو على جند أهل سمرقند

108 Al-Ṭabarī, Ta'rīkh, 2, 1920.

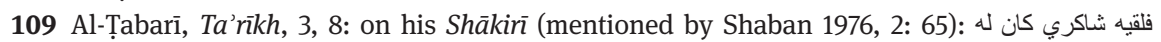

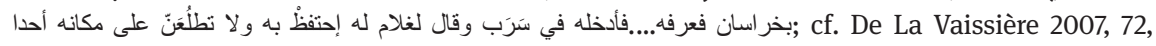
with a different translation: “"Āṣim b. 'Umayr ....est fait prisonnier par un chākar, qui le connaissait car il lui avait été attaché au Khorassan.” On the execution of 'Āṣim b. 'Umayr, see al-Ṭabarī, Ta'rīkh, 2, 1691; on him, see also Akhbār al- 'Abbās, index.

110 Wellhausen 1963, 496. 
enemy and were on their guard against them." The isnād is as follows: 'Ali $\mathrm{b}$. Muhammad [al-Madā'inī] < his authorities (ashyākhihi). ${ }^{111}$

\section{B/16) Khurāsān; Marw: NM/SE?}

The same date (128 H/745-746 CE), the same isnād. Two commanders of alKirmānī unhorsed $A^{\prime}$ 'yan, the mawlā and one of the chief clerks (in charge of the ink stand) of the governor Nașr b. Sayyār, killed him, and killed some of his Shākiriyya (as well). ${ }^{112}$ While the previous source references the Shākiriyya of a distinguished Arab tribal leader (most probably of a military nature), this evidence speaks of the Shäkiriyya of the chief clerk of the governor, a mawlā. One wonders whether this Shäkiriyya consisted of soldiers at all. Nothing is said regarding their ethnic origin or social status.

\section{B/17) Between 105 H/724 CE and 107 H/725-726 CE: NM/SE?}

Ibn al-'Adīm quotes from the book of Abū Hafṣ, 'Amr b. al-Azraq al-Kirmānī (flourished in the first half of the $9^{\text {th }}$ century), "The History of the Barmakīs" (Akhbār al-Barāmika), ${ }^{113}$ who heard from an eyewitness (Ishāa al-Balkhī the

111 Al-Ṭabarī, Ta’rīkh, 2, 1927, 11. 12-14: وبعث تميم بن نصر شاكريته و هم في دار الجنوب بنت القعقاع فرماهم أصحاب الكرماني من السطوح ونذروا بهم ; [my emphasis]; Forand 1962, 11; the Shākiriyya were stationed in a dār. This must have been a huge dār with a large court. There are many examples of descriptions in the Arabic sources of such very big dārs comprising many buildings and a very large court. 112 Al-Ṭabarī, Ta’rīkh, 2, 1928, 1l. 4-5: فصر عوا أعين مولى نصر وقتلوه وكان صاحب دواة نصر وقتلوا نفرا من شاكريته; the isnād starts on 1917.

113 Very little is known about Abū Ḥafs, 'Amr ['Umar?] b. al-Azraq al-Kinānī. He is thoroughly discussed in Bosworth 1994. He wrote a book on the history of the Barmakīs, briefly discussed by Bouvat 1912, 19, who quoted Abū Hafṣ especially through the citations of the mid-14 $4^{\text {th }}$ century Persian work of 'Abd al-Jalīl Yazdī, Ta'rīkh Āl Barmak (Bouvat 1912, 10-13); Sourdel 1959-60, 129, mainly relying on Bouvat. Both Sourdel (1959-60, 130-131) and Bouvat noticed several citations from Abū Ḥafș’ work, mainly in Yāqūt, Mu jam (Wüstenfeld ed.), 4, 817 (Beirut ed., 5, 307) [= Ibn al-Faqīh, Buldān, 232-235 (with slight changes)]. Yāqūt is the only Arabic source quoted by Bouvat and Sourdel that mentions our author by name (rendering 'Umar instead of 'Amr), but neither he nor Ibn al-Faqih mention the title of the author's book. The first to cite the title Akhbār al-Barāmika was Rosenthal 1968, 429, footnote 3, according to the manuscript of Ibn al-'Adìm, Bughyat al-țalab (Paris ms. ar. 2138, fol. 15b.). Rosenthal 1968 and Bosworth 1994 name him 'Umar, but in all cases he is quoted by Ibn al-'Adìm (Bughya, 3, 1547; 7, 3019 (ed. Sezgin, 6, 651); 10, 4706 (ed. Sezgin, 10, 451); 4753 (ed. Sezgin, 10, 484), his name is 'Amr; but see al-Khațīb al-Baghdādī, Ta'rīkh, 10, 184; Ibn 'Asākir, Ta'rīkh, 16, 7 (the title of the 
poet, of whom it is said that he lived in Ruṣāfat Hishām b. 'Abd al-Malik during the latter's reign) who saw Barmak (the ancestor of the Barmakīs), arriving at Hishām's palace in al-Ruṣāfa at the head of 500 Shākirī. ${ }^{114}$ This occurred at the beginning of Hishām b. 'Abd al-Malik's reign (between 105 H/724 CE and 107 H/ 725-726 CE). ${ }^{115}$

Barmak was a Buddhist high priest of the temple of Nawbahār near alBalkh. ${ }^{116}$ According to Abū Hafș, 'Amr b. al-Azraq al-Kirmānī, Barmak arrived at al-Ruṣāfa with his son Khālid, where (according to several traditions) he was converted to Islam at the hands of the caliph himself. ${ }^{117}$ Even if the number

book is rendered differently [?]: في أخبار البرامكة وفضائلهم; Yāqūt, Mu'jam (Wüstenfeld ed.), 4, 817 (Beirut ed., 5, 307): in the last three sources his name is given as 'Umar. He transmitted directly from al-Jāhịiz (d. 255 H/869 CE) (Ibn al-'Adīm, Bughya, 7, 3020). In another tradition, transmitted by the famous poet Abū Tammām, Ḥabīb b. Aws (d. 231 or 232 H/845 or 846 CE), caliph alMa'mūn (d. 218 H/833 CE) demands Abū Ḥafș, 'Umar [read 'Amr] b. al-Azraq al-Kirmānī to be his wazir and the latter refuses politely and wittily (al-Khațīb al-Baghdādī, ibid.).

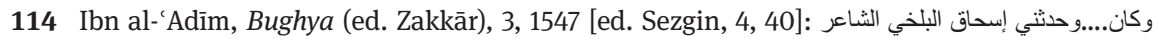

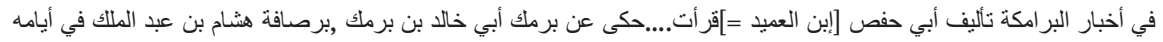

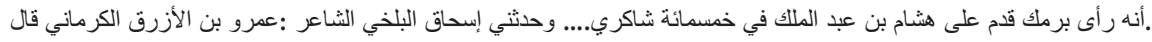

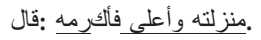

115 In 107H/725-726 CE, Barmak was appointed as governor of Balkh by Asad b. 'Abdallāh alQasrī. See al-Ṭabarī, Ta'rīkh, 2, 1490 [= Ibn al-Athīr, al-Kāmil (Beirut ed.), 4, 378]; Ibn al-Jawzī, alMuntazam, 6, 118; Ibn Taghrībirdī, al-Nujūm, 1, 261.

116 Sourdel 1959-60, 1: 129-133; Abbas 1988; Barthold-[Sourdel]), “al-Barāmika,” EI , 1, 1033. 117 Ibn al-'Adīm, Bughya (ed. Zakkār), 3, 1547 [ed. Sezgin, 4, 40]; see also the long and detailed traditions of Abū Ḥafṣ al-Kirmānī about Barmak and his son, Khālid at Hishām's court at al-Rușāfa. Ibn al-'Adīm, Bughya (ed. Zakkār), 7, 3019ff. Cf. the reserved and cautious remarks of Crone 1980, 76 (relying on Bouvat 1912, 32): “...a similar behavioural pattern is exemplified in the story that Barmak had gone to the caliph's court to convert." Sourdel 1959-60, 1: 132 casts doubt on the authenticity of the traditions about Barmak's associations with the Umawi caliphs 'Abd alMalik and Hishām, arguing against Bouvat's assertions ("mais tout le reste paraît être pure légende...Nous n'oserons donc pas dire, après L. Bouvat, que 'Barmak et son fils Khalid, par leurs mérites et leurs richesses, exercèrent une grande influence à la cour des khalifes umayyades).” D. Sourdel, in Barthold-[Sourdel]), "al-Barāmika," $E I^{2}, 1,1033$ : "He is a figure known to us by information which is to a large extent legendary. Thus it is that he is held to have possessed medical knowledge and to have treated among other patients [the text lists only one patient, Maslama; no other person is mentioned] on which he bases the Umayyad prince Maslama b. 'Abd alMalik (al-Tabarī, Ta'rīkh, 2, 1181)." See also Sourdel 1959-60, 1, 132, note 2: "mais tout cela reste très hypothétique." It seems that the information about Barmak's skills as a physician is corroborated by the tradition recorded by Ibn al-'Adìm, Bughya, 7, 3019. The prince was Maslama b. Hishām b. 'Abd al-Malik, and not Maslama b. 'Abd al-Malik as Sourdel believed (his source, alTabarī, Ta'rīkh, 2, 1181 mentions Maslama, with no name of the father added). The tradition was related by Sa'īd b. Maslama b. Hishām b. 'Abd al-Malik to Abū Ḥaf̣̦, 'Amr b. al-Azraq al-Kirmānī, and was read by Ibn al-'Adīm from the former's book on the History of the Barmakīs, describ- 
of Shākirīs is exaggerated, the narrator defines a big company who came with Barmak as Shākirīs. In the case of Barmak the Buddhist priest, it is doubtful that they were a personal military guard and so were probably not similar to the Shäkiriyya contingents in the service of the Soghdian noblemen in Transoxania. Nothing is said about their ethnic origin or social status.

It is noteworthy that both Bosworth and De La Vaissière interpret this text differently. Bosworth's translation reads: "[H]e saw Barmak brought before Hishām b. 'Abd al-Malik in a body of 500 slaves (shākirī). Hishām treated him أنه رأى برمك قدم على هثام بن عبد الملك في:at خمسمائة شاكري should be rendered: “He arrived [at Hishām's court] at the head of 500 shākirī.” De La Vaissière translated (following Bosworth): "Barmak fut conduit devant Hishām b. 'Abd al-malik au sein d'un groupe de 500 shākir...." De La Vaissière concludes in regard to this text that:

Un corps de 500 chākar aurait été présenté au calife omeyyade Hishām (724-743) à Damas. Ce sont sans doute des prisonniers capturés au Tokharestan, car parmi eux se trouvait l'ancêtre des Barmécides, gardien du grand monastère bouddhique, le Nawbahar de Balkh. ${ }^{119}$

This text has served as a basis for arguing for the Central Asian rather than Middle Eastern origin of the Shākiriyya in the early 'Abbāsī period within the elites of the 'Abbāsī court. The Barmakīs are also considered by De La Vaissière to have been military troops ("étant donnée l'origine centre-asiatique des troupes comme des Barmécides...”), ${ }^{120}$ but this cannot be deduced from the Arabic text.

\section{Partial Conclusion}

Forand argues, following some of the examples above (nos. B/4, B/10; see also n. 121 below, al-Aghānī), that:

...the shākiriyyah as it occurs in the Arabic sources refers to a corps of slaves, partly domestic and partly military, in attendance upon the person of local potentates in Iran and central

ing how Barmak treated his father and cured him (perhaps of impotence). These traditions from the book of Abū Hafș were not known to Sourdel; Ibn al-'Adìm's Bughya was still unprinted when Sourdel's book was published. See the detailed discussion of this matter by Bosworth 1994, 270-271.

118 Bosworth 1994, 273-274.

119 De La Vaissière 2007, 144; see also 155.

120 De La Vaissière 2007, 150: argues against Gordon's view of the Middle Eastern origin of these units. 
Asia...it is impossible to establish beyond a doubt that individuals constituting a shākiriyyah among the Umayyads were of servile status the shäkiriyyah of the Iranian rulers must have been slaves.

This unequivocal conclusion cannot be derived from the texts quoted by Forand. ${ }^{121}$ He finds support for this assertion from the fact that in all the cases he checked the term Shākiriyya "occurs with the possessive pronominal suffix and in each case it would be rendered into English as 'his shākiriyyah', possibly indicating the master's actual possession of the servant." ${ }^{122}$ Unfortunately, mere use of the possessive pronoun does not enable us to understand the nature of the Shākiriyya nor the nature of the connection between the leader and his Shäkiriyya. Moreover, one of the decisive pieces of evidence for the slave nature of the Shäkiriyya is the "passage in Tabari (II, 1159-1160), where an incident is described in which Tarkhūn threatens to exercise his right of life and death over the members of his shäkiriyyah." ${ }^{123}$ The Arabic text (al-Ṭabarī, II, 11591160) does not imply any such assertion. Forand's conclusions were accepted in full by Yonggyu, so the same reservations regarding Forand's conclusions and method can be applied to Yonggyu's treatment of the Arabic sources regarding al-Shākiriyya. ${ }^{124}$ In regard to the last piece of evidence adduced by Forand, Yonggyu says inaccurately that, "In fact Țabarī provides many examples [! my emphasis] that the Iranian ruler had the right of life and death over the members of the Shākiriyya."125

121 Forand 1962, 10 (al-Ṭabarī, Ta'rīkh, 2, 1159-1160, 1604); 11: corps of slaves. The text in alIṣfahānī, al-Aghānī (ed. Būlāq), 14, 110: فلما نظرَتُ في وجهي سترت وجهها فأخبرني شاكري أن المر أة هي أم شارية جارية إبر اهيم, is certainly equivocal. See also the discussion below.

122 Forand 1962, 11.

123 Forand 1962, 11.

124 Yonggyu 2004, 41-42, 68, quoting Forand's text and sources, 10-11; 68: "The great Islamic historian Țabari seems to have understood the chākar as someone who was possessed by the ruler." Here Yonggyu also follows Forand's argument about the use of "the possessive pronominal suffix with the term Shākiriyya" concluding "Thus, this Arabic expression...is used to indicate the master's actual possession of the servant." It is almost superfluous to remark that this is not al-Tabarì's interpretation, but that of his early sources.

125 Yonggyu 2004, 68, quoting Forand 1962, 11; and several references from al-Ṭabarī, also after Forand, but the only citation for this matter brought by Forand, that is al-Tabarī, Ta'rikh, 2, 1160, is not mentioned by Yonggyu. 


\section{C) The 'Abbāsī Period}

\section{C/1) [18]: MC/SE?}

The first piece of evidence is connected to the famous $2^{\text {nd }} / 8^{\text {th }}$-century șūfĩ Ibrāhīm b. Adham (ca. 112 H/730-161 H/777 CE). ${ }^{126}$ It is recorded by Abū Nu'aym al-Ișfahānī (d. 430 H/1038-1039 CE) through 'Abdallāh b. Aḥmad b. Sawāda (d. 285 H/899 CE in Ṭarsūs), ${ }^{127}$ < al-Hasan b. Muhammad (unidentified) < Bakr (unidentified): 'Abbās b. al-Faḍl al-Mar'ashī (unidentified) related to me:

I met 'Abd al-'Azīz b. Abī Rawwād and we exchanged memories regarding Ibrāhīm b. Adham's matter [that is, his becoming a Șūfī]. 'Abd al-'Azīz said: 'May God have mercy on Ibrāhīm b. Adham, I have seen him in Khurāsān, whenever he rode there were about 20 Shākirīs in front of him, but [in spite of all this], may God have mercy on him, he was looking for the middle place [that is, the best part] in Paradise. ${ }^{128}$

'Abd al-'Azīz b. Abī Rawwād (d. 159 H/775-776 CE) was a mawlā of al-Muhallab b. Abī Șufra al-Azdī, a pious (Șūfì) hadìth scholar and adherent of the Murji'a school. His family was originally from Khurāsān, where he could have met Ibrāhīm b. Adham. He moved to Mecca, where he died. ${ }^{129}$

\section{C/1.1-1.3) [18.1-3]}

Three variants of this tradition were recorded by Ibn 'Asākir. The first was transmitted through Abū 'Uthmān al-Aswad, 'Abd al-Malik b. Sa'īd, whose nickname was rafì Ibrāhìm b. Adham (the companion [in travels/journeys] of Ibrāhīm b. Adham), ${ }^{130}$

126 On him, see Jones, "Ibrāhīm b. Adham," $E I^{2}$, 3, 985-986.

127 On him, see Ibn Ḥibbān, Ṭabaqāt al-muhaddithīn, 3, 292; al-Khațīb al-Baghdādī, Ta’rīkh, 9 , 381; Ibn 'Asākir, Ta'rìkh, 27, 31-33.

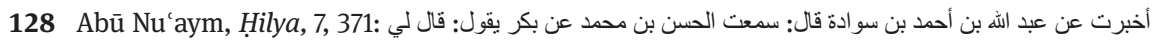

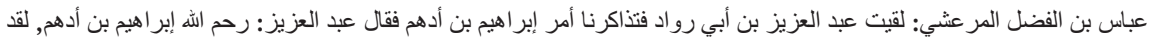

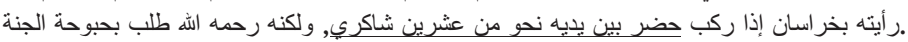

129 On him, see al-Bukhārī, al-Kabīr, 7, 22: Mawlā al-Muhallab b. Abī Șufra al-Azdī; Ibn Ḥibbān, al-Majrūhịn, 2, 136-138; Ibn Mākūlā, al-Ikmāl, 4, 105-107: biographies of his extended family; al-Dhahabī, Mīzān, 4, 364-365; idem, Siyar, 7, 184-187; al-Mizzī, Tahdhīb, 18, 136-139. 130 Ibn 'Asākir, Ta'rīkh, 37, 18 (a short biography). I was not able to find additional information on him. 
... from Abū 'Uthmān al-Aswad, who accompanied Ibrāhīm b. Adham for 14 years, who said: "I went to Mecca for the Hajj and I met 'Abd al-'Azīz b. Abī Rawwād who said to me: 'What has become of your brother?' I said: 'He is in al-Shām, in such and such a place.' He said: 'I met him and saw him in Khurāsān, riding with 30 Shākirīs in front of him but he preferred to be in the best place (centre) of Paradise.'

The two variants are very similar with minor changes. ${ }^{131}$

\section{C/1.2) [18.2]}

Another similar but garbled tradition is allegedly transmitted by a different wellknown șūfī, Shaqīq b. Ibrāhīm al-Balkhī, who relates in the first person how he met Ibrāhīm b. Adham in al-Shām:

And I had seen him in al- 'Irāq [sic. Variant reports: Khurāsān [?]] with 30 Shākirīs in front of him. I said to him: 'You have left the kingdom of Khurāsān (تركت ملك خراسان) and departed from your pleasant privileged life;' but he said: 'Be silent, I have not enjoyed bread [life?: تهنيت بالعيش], except here [that is, in al-Shām].'132

\section{C/1.3) [18.3]}

Several sources record the last part of the tradition without the section that mentions al-'Irāq and the 30 Shākirīs in the kingdom of Khurāsān. It seems that Ibn Kathīr mixed together two different separate traditions. ${ }^{133}$

As is well known, Ibrāhīm b. Adham was born in Balkh, Khurāsān, and migrated to Syria some time before $137 \mathrm{H} / 754 \mathrm{CE}$. Jones claims that:

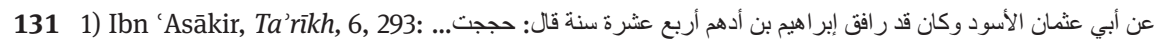

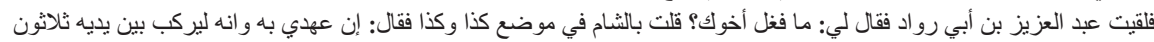

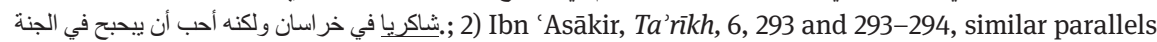
with small changes (Khurāsān is omitted); 3) Ibn 'Asākir, Ta'rīkh, 6, 293, another parallel, the

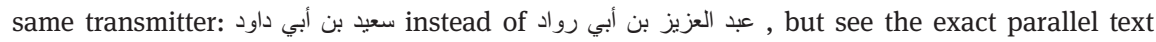

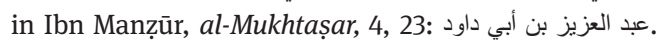

132 Ibn Kathīr, al-Bidāya, 10, 146 (biography of Ibrāhīm b. Adham).

133 The last part is recorded as a separate tradition by Abū Nu'aym, Hilya, 7, 369; Ibn al-Jawzī,

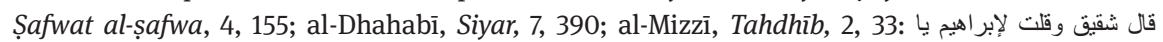
the isnād (in Abū Nu'aym's and al-Mizzī’s works): ...Abū Ya'lā < 'Abd al-Ṣamad b. Yazīd I heard Shaqīq al-Balkhī...; 'Abd al-Ṣamad b. Yazīd was a well-known muhaddith and Șūfì who died in 253/867. On him, see for example, Ibn Ḥibbān, al-Thiqāt, 7, 415; Ibn Abī Ḥātim, al-Jarh, 6, 52; al-Khațīb al-Baghdādī, Ta'rīkh, 11, 40; al-Dhahabī, Mìzān, 4, 356; Ibn Ḥajar, Tahdhīb, 6, 293. 
Ibrāhīm b. Adham is known widely in legend as the ruler of Balkh, who abdicated his throne to take up the ascetic life...[but there]...seems to be no historical basis for this belief. The first source to give him royal status is al-Sulamī (d. 412 H/1021 CE), the legendary nature of whose account is sufficiently demonstrated by the fact that it includes a description of Ibrāhīm's encounter with the immortal prophet Khiḍr; however, from al-Sulamī onwards this legend is found firmly rooted in the accounts of Ibrāhīm's life. ${ }^{134}$

Without going deeper into this topic which is far from my scholarly expertise, suffice it to say that even from a cursory reading of some of the relevant sources on Ibrāhīm b. Adham (e.g., the works of Abū Nu'aym, al-Qushayrī, al-Sulamī and Ibn 'Asākir), it can be argued that these authors did not invent the traditions, they relied upon earlier sources and traditions and quoted them faithfully. By checking the isnāds of the (relatively) late sources, it can be safely argued that Ibrāhīm's noble Iranian [?] origin was well established in the $8^{\text {th }}$ century. ${ }^{135}$ The imaginative, inventive, colourful and clearly biased traditions that describe his revelations and awakening from the earthly, materialistic world must have had some basis. Not every șūfi was a noble prince. Even if the traditions about the 20 or 30 Shākirīs of Ibrāhīm b. Adham were invented, they were beautifully invented, based on a real kernel of history. The term was widely current in the $8^{\text {th }}$ century and well known to the authors, who naturally assumed that a noble Khurāsānī must have had Shākirs. What the nature of these Shākirs was cannot be ascertained from these traditions.

The following examples are from the reign of Abū l-'Abbās al-Saffāḥ (r. 132 H/750 CE-136 H/754 CE).

\section{C/2) [19] Khuttal, Transoxania, 133 H/750-751 CE: MC?}

In this year, the governor of Balkh on behalf of Abū Muslim, Abū Dāwūd, Khālid b. Ibrāhīm al-Raba'ī, al-Dhuhlī,

set out from al-Wakhsh towards al-Khuttal and entered the city. The king of the province, H.n.sh b. al-S.b.l offered no opposition to him; a group of the dahāqin of al-Khuttal came to him and entrenched themselves with him. Some of them fought in the roads, mountain passes and the fortresses. When Abū Dāwūd laid a close siege on the fortress, the king went out of the fortress at night; with him were his dahāqīn and Shākiriyya until they arrived at the land of Farghāna, then he left it, and through the land of the

134 Jones, "Ibrāhīm b. Adham," $E I^{2}, 3$, 985-986.

135 The many traditions in his biographies in Abū Nu'aym, Hilya, 7, 367-395; 8, 3-58, and Ibn 'Asākir, Ta'rīkh, 7, 277-352, can serve as case studies. 
Turks reached the king of China; Abū Dāwūd took whoever he managed to take as prisoners and brought them to Balkh, then he sent them to Abū Muslim. ${ }^{136}$

\section{C/3)[20] al-'Irāq, al-Kūfa/al-Hāshimiyya (?), 136 H/754 CE: SE/SL/NM?}

Al-Muṭahhār b. Tāahir reports that Abū l-'Abbās al-Saffāḥ, under the influence of his brother al-Manșūr, plans to kill Abū Muslim, but at the last moment when Abū Muslim enters the caliph's chamber the latter "said to one of his Shākiriyya: Tell Abū Ja far not to do it” ( فقال لبعض شاكريته قل لأبي جعفر لا يفعل ذلك a.... 137 This affair is described at length by al-Ṭabarī, partially quoting al-Madā'inī. ${ }^{138}$ Ibn Ṭāhir combined parts of these same traditions and created one long tradition, omitting his sources. In al-Tabarī’s tradition, the Shākirī turns into a eunuch (khașiyy).

It was said (qüla) that Abū l-'Abbās [al-Saffāh], when he gave permission to Abū Ja'far [alManșūr, his brother] to kill Abū Muslim, the latter entered the audience of Abū l-'Abbās. The caliph sent one of his eunuchs ordering him: 'Go and see what Abū Ja'far is doing.' The eunuch came to him and found him in a sitting position, his sword put against his knees (محتبيا بسيفه). Abū Ja'far asked the eunuch: 'Is the Commander of the Faithful sitting (for an audience)?' The eunuch answered: 'He is getting ready for the sitting.' Then the eunuch came back to Abū l-'Abbās and told him what he saw; the caliph sent him back to Abū Ja 'far telling him: 'Do not carry out what you had planned to do,' so Abū Ja 'far withdrew from what he had planned. ${ }^{139}$

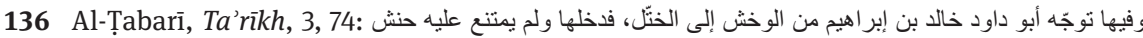

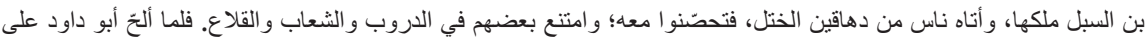

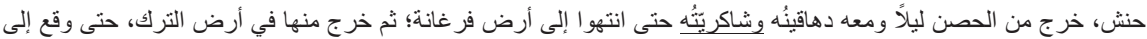
ملك الصين؛ وأخذ أبو داود من ظفر به منهم، فجاوز بهم إلى بلخ، ثم بعث بهم إلى أبي مسلم

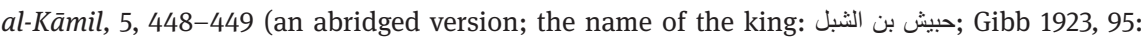
adding that in China the king was given the title Jabghu in recompense for his resistance. Abū Dāwūd was one of the 12 nuqabā' of the 'Abbāsī $d a^{\prime} w a$, and one of its senior commanders; on him, see Agha 2003, Appendix One, 356, no. 237; on al-Khuttal, see Bosworth, "Khuttalān, Khuttal," $E I^{2}, 5,75-76$. Bosworth briefly mentions this event. On Wakhsh, located in the vicinity of al-Khuttal on the Oxus, see Bosworth, "Wakhsh," $E I^{2}, 11,100-101$; briefly mentioned by De La Vaissière 2007, 72: "le roi du Khuttal s'enfuit au Ferghana avec ses nobles et sa shākiriyya."

137 Al-Muțahhar b. Țāhir, al-Bad', 6, 76.

138 Al-Ṭabarī, Ta'rīkh, 3, 85-86.

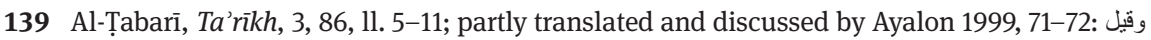

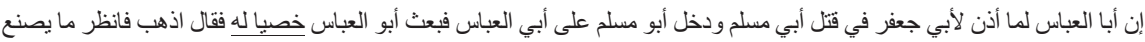

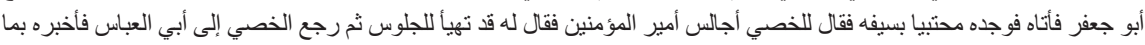

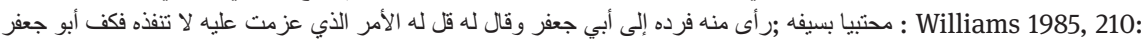
"sitting on his heels propped by his sword." For a description of this kind of sitting, see Lane, Lexicon, h.b.w.: "for the Arabs not having walls in their deserts to lean against in their assem- 
Noteworthy is another parallel text (quoted almost verbatim from al-Tabarī or his source) in (pseudo-) Ibn Qutayba's al-Imāma wa-l-siyāsa, but here, the term eunuch (خصِيّ) is used interchangeably with another term, وصيف 140 Ayalon concludes his discussion on the wașif by saying:

As for the term itself, it was mainly used as a designation for a particular stage of slavery (of non-eunuchs or eunuchs). It was also a proper name. Thus wașiff (or wașifa) usually denoted a very young slave or slave-girl, at the early period of their service in their patron's court... ${ }^{141}$

Regarding the long tradition of al-Tabarī, Ayalon concludes: "Even if this account is not historically true, it certainly reflects truly the unlimited reliability of the eunuch [or the Shäkiryya of the caliph according to the first version of the tradition]."142

The following examples are from the reign of al-Manșūr (r. 136 H/754 CE-158 $\mathrm{H} / 775 \mathrm{CE})$.

\section{C/4) [21] Irāq, Baghdād (?): MC?NM?}

A long tradition related from Ṭayfūr, al-Manșūr's mawlā, who relates part of his tradition from al-Rabī' b. Yūnus, al-Manșūr's mawlā and his hājib, who reports in the first person about al-Manșūr's dream which caused him to leave Baghdād at the head of the hajj caravan from al-'Irāq. The tradition is combined with extensive legendary and literary motifs. On their way they stayed in al-Najaf for a few days. Al-Rabī' says: "When al-Manșūr ordered to move on, his army and [? the

bling, the man used to set up his knees in his sitting, and put against them a sword, or surround them [and his back] with a piece of cloth, or knit his hands, or arms, together upon them, and rest against them...”

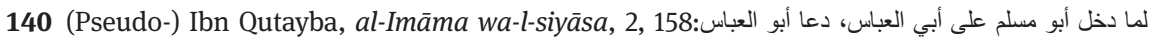

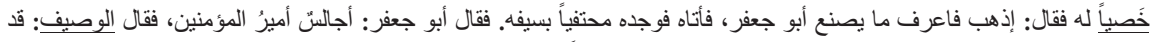

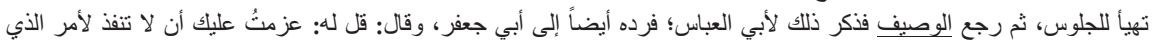
عزمتَّ عليه، فكف عن ذلان للك.

141 Ayalon 1999, 282; for the discussion on the wașiff, see ibid., 281-284; on the interchangeability of the terms, see ibid., $273 \mathrm{ff}$.

142 Ayalon 1999, 72. Ayalon did not analyse the account in al-Bad' wa-l-Ta'rikkh, where the eunuch (in al-Ṭabarī's narration) becomes a Shākirī. 
word is unclear] moved on while I and he [the caliph] remained in the Qașr while his Shākiriyya [was stationed] at the gate (وبقيت أنا و هو في القصر وشاكريته بالباب)."d

This is a typical conventional tradition, one of many that provides inner 'domestic' information about al-Manșūr such as dreams, palace or court intrigues and the like, often from servants, mawāli or slaves/(both female and male), secretaries or chamberlains of the caliph and even from his mother. ${ }^{144}$

The following examples are from the reign of Hārūn al-Rashīd (r. 170 H/786 CE-193 H/809 CE).

\section{C/5) [22]: SE?/MC?}

The Shākiriyya of Yaḥyā b. Khālid al-Barmakī, al-Rashīd's wazīr:

Ibn Mazrū' related from his father who said: 'While riding along with the entourage of Yaḥyā b. Khālid [al-Barmakī, d. 190 H/805 CE], a common man carrying a letter appeared before him and said: "May God bestow his favours on the Amir; sign this letter"; but the Shākiriyya hastened towards him, chiding him away from the sides of his cortège, but he (Yahyā) said: 'Leave him alone' ... and he asked him to get closer and signed the letter for him. ${ }^{145}$

Ibn Mazrū' is Nașr b. Mazrū' al-Kalbī, one of the earliest Arab genealogists, who composed a book about the vices of the Arabs (mainly dealing with defects in, or causes of blame or reviling of, the lineage of Arab notables: مثنالب).146

143 Ibn 'Asākir, Ta'rīkh, 32, 340-341: بو انبه][?] وجنده: Ibn al-Jawzī, al-Muntazam, 8, 220, and Ibn al'Arabī, al-Futūḥāt al-makiyya, 4, 546: نوابه وجنده: the isnād :...... Manșūr b. Abī Muzāhịim < Abū Sahl al-Ḥāsib < Ṭayfūr; Manșūr b. Abī Muzāḥim (Bashīr) was a kātib of Turkish origin, who held a secretarial office in Baghdād. He left it to dedicate his life to the study and transmission of hadìth and died in 235 H/850 CE; on him, see al-Bukhārī, al-Kabīr, 7, 349; Ibn Abī Ḥātim, alJarḥ, 8, 170; Ibn Ḥibbān, al-Thiqāt, 9, 173; al-Khațīb al-Baghdādī, Ta'rīkh, 13, 80-82; Ibn 'Asākir, Ta'rīkh, 60, 304-310; 305: وكان له ديوان وتركه. I was not able to identify Abū Sahl al-Ḥāsib. 144 For example, Ibn 'Asākir, Ta'rīkh, 32, 303; 69, 231; al-Khatịib al-Baghdādī, Ta'rīkh, 1, 87: a similar isnād to the previously discussed tradition which ends, however, with al-Manșūr's mother: ....Manșūr b. Abī Muzāḥim < Abū Sahl al-Ḥāsib < Ṭayfūr mawlā amīr al-mu'minīn < Salāma umm amìr al-mu'minin: about a dream she had while pregnant with al-Manșūr.

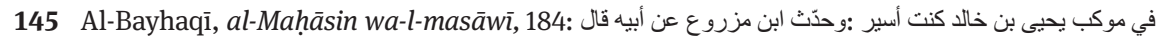

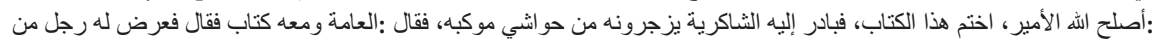
واستدناه فختمه له .....دعوه له رجل

146 So far I have not found a biography dedicated to him; he is not mentioned by Rosenthal, Duri (Conrad), Humphreys, Khalidi or Robinson, or by Brockelmann (Geschichte der Arabischen Litteratur) and Sezgin 1967; nevertheless he is quoted in the sources (mainly relating to the genealogy of Arab tribes and notables), e.g. al-Ișfahānī, al-Aghānī (ed. al-Hay'a al-Miṣriyya), 20, 75, 


\section{C/6) [23]: SE?/MC?}

From the second piece of evidence it is learned that Yazīd b. Mazyad al-Shaybānī (d. 183 H/799-800 CE), one of Hārūn al-Rashīd's senior commanders, ${ }^{147}$ sent one of his chamberlains (ahad hujjābihi) from al-Raqqa in al-Jazira with a gift of money to the poet Muslim b. al-Walīd (d. $208 \mathrm{H} / 823$ CE). ${ }^{148}$ The hājib, dressed in black clothes, a woolen head cover, and a girdle, was accompanied by a Shākirī. ${ }^{149}$ No information is given about this Shākirī, who may have been a soldier, one of the Shākiriyya of Yazīd b. Mazyad (if he had one), or a domestic servant/slave.

\section{C/7) [24] al-'Irāq. Baghdād (?): SL/SE}

Al-Mas'ūdī records an account by Muhammad b. 'Alī al-'Abdī al-Khurāsānī alAkhbārī (d. after 332 H/943 CE), ${ }^{150}$ related by him to caliph al-Qāhir (r. 320 H/ 932 CE-322 H/934 CE): Zubayda, Umm Ja'far, Hārūn al-Rashīd's wife and alAmin's mother, “was the first [among the caliphs' wives?], who employed the Shākiriyya, the eunuchs and the slave-girls in all kinds of duties and messages, performing them on (the back of) riding animals, going out to fulfil her needs with her letters and epistles."151

where he is mentioned among those authors that composed a book on the mathălib [of the Arabs] ; al-Mas'ūdī, al-Tanbīh wa-l-ishrāf, 81, 1. 13; Abū l-Baqā', al-Manāqib al-mazyadiyya, 1, 302, 327-329, where he is termed Nașr b. Mazrū' al-Kalbī al-Nassāba; Ibn 'Asākir, Ta'rīkh, 47, 348; Ibn al-Athīr, Usd al-ghāba, 5, 605.

147 On him, see Crone 1980, 169.

148 On him, see al-Ziriklī 1980, 7: 223; Kaḥhāla 1957-61, 12: 233; Sezgin 1967, 2, 528-529; I. Kratschkowsky, "Muslim b. al-Walīd," E.I ${ }^{2}$, s.v.

149 Al-Ișfahānī, al-Aghānī, 19, 42 (ed. Samīr Jābir, Beirut, Dār al-Fikr, n.d.):

فإذا رجل عليه سو اد وشاثشية ومنطقة ومعه شاكري 50; Ibn Munqidh, Lubāb, 138.

150 On him, see Rosenthal 1968, 52-53; al-Mas'ūdī, Murūj, 7, 658: index prepared by Ch. Pellat, the editor.

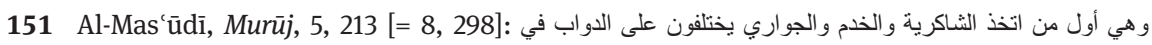
جهاتها ويذهبون في حو ائجها برسائلها وكثبها ly translated with a discussion (not on the Shākiriyya, though) by Ayalon 1999, 129 (translation) and 130; I relied on Ayalon's translation. 
I understand the expression al-Shākiriyya here not as a military unit, but perhaps as household attendants. They are mentioned together with other domestic servants and slaves who performed secret or discreet errands for Zubayda. ${ }^{152}$

\section{C/8) [25] al-'Irāq. Baghdād: MC}

Al-Rashīd b. al-Zubayr records in his book al-Zakhā'ir wa-l-tuhaf (written in 463 H/1070-1071 CE) a long tradition from al-Faḍl b. al-Rabī' (the son of the abovementioned al-Rabī' '), the famous wazīr of Hārūn al-Rashīd and al-Amīn, in which he gives a long detailed description of the clothes, fine objects, weapons etc. that were found in Hārūn al-Rashīd's store houses (الخزائن) upon al-Amīn's ascendance to the caliphate. Among the weapons he mentions " 50,000 swords of [for?] the Shākiriyya and the slaves (الغلمان)."153

\section{C/9) [26] al-'Irāq, Baghdād (?): SE/NM}

The famous singer Mukhāriq relates that he visited the poet Abū l-'Atāhiya alone

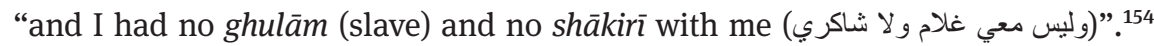

The following examples are from the reign of al-Amīn (r. 193 H/809 CE-197 $\mathrm{H} / 813 \mathrm{CE})$.

\section{C/10) [27]: SE/NM}

Upon ascending the caliphate al-Amīn took the famous singer 'Arīb from her owner for himself. Her owner 'Īsā b. 'Abdallāh b. Ismā'īl, known as the Marākibī

152 Forand's translation of this text (1962, 11-12): "the first (of the Abbasid house) to form a shäkiriyya to wait upon her personally and serve as a mounted cortege when she went out in public," is not accurate. De la Vaissière 2007, 146 translates: "la première qui organisa une troupe de chākar, d'eunuqes et de filles esclaves, qui chevauchaient à ses côtés, exécutaient ses ordres...” I follow Ayalon's translation of the Arabic phrase: يختلفون على الدواب في جهاتها.

153 Ibn al-Zubayr, al-Zakhä'ir, 214 (the beginning of the inventory), 217 (the 50,000 swords) [my emphasis]; quoted by al-Ḥamawī, Thamarāt al-awrāq, 405; al-Ghazūlī, Mațāli` al-budūr, 2, 479 (both quote al-Rashīd b. al-Zubayr); De La Vaissière 2007, 146, note 382 (quoting al-Rashīd b. al-Zubayr).

154 Al-Raqīq al-Qayrawānī, Quṭb al-surūr, 622. 
(that is, the one who is in charge of the royal stables), passed by the new caliph and wanted to kiss his hand but the caliph, who held a grudge against him,

ordered that he be held back (from him); the Shākirī did this, but the Marākibī beat him and said: 'Do you prevent me from kissing the hand of my master?' When the caliph dismounted, the Shākirī came and complained against al-Marākibī, so al-Amīn summoned him and ordered that his head be cut off. ${ }^{155}$

One wonders if the Shākiri who was beaten was really a soldier and one of the caliph's bodyguards, as asserted by Forand. ${ }^{156}$

The following examples are from the reign of al-Ma'mūn (r. 198 H/813 CE218 H/833 CE). ${ }^{157}$ There are a few instances in the early 'Abbāsī caliphate in which a Shākirī or a Shākiriyya are in the service of a caliph. In the period of al-Ma'mūn's rule, a military unit named "al-Shākiriyya" is mentioned in the service of the caliph. It is also recorded by the sources that some of al-Ma'mūn's senior commanders had Shākiriyya contingents in their service.

\section{C/11) [28]: MC}

The first piece of evidence we have is from Marw, Khurāsān between the years 193 H/809 CE and 202 H/817 CE. It is related by al-Rayyān b. al-Ṣalt, one of the close associates of al-Ma'mūn's wazīr, al-Faḍl b. Sahl: "I was summoned one day by him (al-Faḍl), who informed me that he wished to gather for me 4,000 [soldiers] from the Shākiriyya and the jund and appoint me as their commander, thereby turning me into one of his commanders, with conditions and rights of his commanders.” Al-Rayyān refuses this proposal. ${ }^{158}$

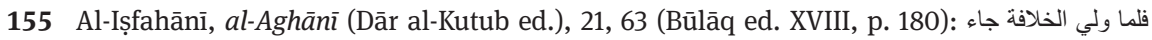

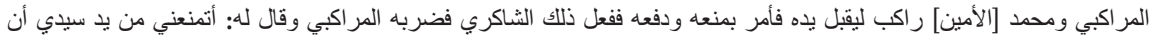

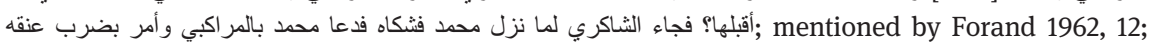
on al-Marākibī, see al-Ziriklī 1980, 5: 105.

156 Forand 1962, 12 (quoting al-Aghānī (Būlāq ed.), 18, 180): “Amīn himself was served by household attendants called, in the singular, shākiri, and who in one instance at least functioned as his bodyguards.” The text does not allow for such farfetched conclusions.

157 The following four pieces of evidence (no. 11[28]-14[31])were also dealt with in Elad 2010, 45-48.

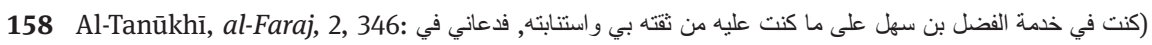

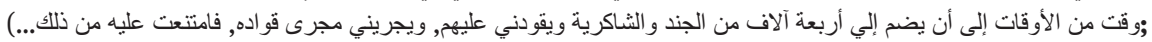
the long tradition was copied by al-Tanūkhī from the lost part of al-Jahshiyārī’s Kitāb al-Wuzarā' wa-l-kuttāb; al-Tanūkhī's text was copied by 'Awwād 1964, 31-36 (the mention of the Shākiriyya 
In the tradition, the joining of the two expressions al-Shākiriyya and al-jund may indicate the different expressions have different meanings, though the term al-Shākiriyya seems to denote a unit with a military character. We do not know the relative size of each unit with any precision, as the number 4,000 also includes soldiers from the army (al-jund). The combination of the terms al-jund and al-Shākiriyya is most common during the Sāmarran period. ${ }^{159}$

\section{C/12) [29]: MC}

The second tradition is from the year $201 \mathrm{H} / 816-817 \mathrm{CE}$, when al-Ma'mūn (still in Khurāsān), decides to nominate 'Alī l-Riḍā as Crown Prince. Therefore he summons the wulāt, the judges, the (senior) commanders (al-quwwād) and the Shākiriyya and the offspring of al-'Abbās, explaining "he wants this matter to be rooted in the hearts of al-'ämma, al-jund and al-Shākiriyya." In the first part of the tradition the army, al-jund, is not mentioned, and al-Shākiriyya appears by itself among groups of notables. Therefore it seems that the Shākiriyya also has a special high status. In the second part, the pairing (this time reversed) of al-jund and al-Shākiriyya appears again. ${ }^{160}$

\section{C/13) [30]: MC}

From a tradition that describes the end of the siege of Baghdad in Muharram 198 H/September 813 CE, we learn that Tāhir b. al-Ḥusayn also had a special unit called Shākiriyya. Taāhir writes to al-Ma'mūn describing how he plans to trap al-Amīn, who wanted to go over to Harthama b. A'yan's camp:

....and I turned with the choicest of the faithful (khāșșat thiqātī) and I relied on them and trusted that they would be brave and determined, and would be unsullied faithful advisors, and I already prepared war ships (harrāqāt) ${ }^{161}$ and (regular) ships (sufun)....And I went down to them with a group that rode with me from among my faithful and my Shäkiriyya.

and the jund is on p. 36); see also De La Vaissière 2007, 157 (according to 'Awwād 1964): with a different interpretation.

159 See Gordon 2001, index (jund and Shākiriyya), esp. 40-42.

160 Ibn Bābuyh al-Qummī, 'Uyūn akhbār al-Riḍā (al-Najaf ed.), 2, 148 (Beirut ed., 1, 161); al-

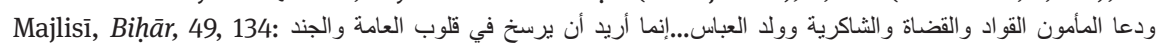
و الثاكرية هذا الأمر 87, 360: the second part of the tradition, from al-Rayyān b. al-Ṣalt.

161 Warships with installations for throwing fire at the enemy whilst at sea or on large rivers (sometimes described as a warship that contains sailors and fighters, see Elad 1986, 68, note 53). 
And I sent a group of them (some of them) riding and some of them on foot between the Gate of Khurāsān and al-Mashra'a [the watering place in the river], and along the banks of the river (al-shatt $)^{162}$

What is mentioned in this tradition is not the jund, the regular army, but the Shäkiriyya. The Shākiriyya is mentioned together with Tāhir's closest and most loyal adherents, and it is possible that the intent here is to a kind of personal select guard, perhaps (though we have no proof of this) connected by ties of wala or even servitude to Tāhir. Almost nothing is given regarding their origin. ${ }^{163}$

\section{C/14) [31]: $M C$}

The fourth tradition in which the Shākiriyya is mentioned is from the year $214 \mathrm{H} /$ 829-830 CE. A number of military missions are defeated by a Khārijī rebel, Bilāl al-Ḍabābī al-Shārī in al-Jazīra. In the end, al-Ma'mūn himself leaves Baghdad, reaches al-Jazira, camps in the village of al-'Alath, and afterwards sends the commanders and al-Shākirdiyya after Bilāl al-Shārī. ${ }^{164}$ From this tradition, it appears that the commanders are at the head of an army which is separate from the special military unit, called Shākirdiyya and not Shākiriyya. Shākird is rendered as a scholar, student, apprentice, a disciple; a boy servant, groom. ${ }^{165} \mathrm{I}$ do not know what the difference (if any) is between the two words.

\section{C/15) [32]: MC? SE?}

Another senior commander of al-Ma'mūn, 'Alī b. Hishām (d. 217 H/832 CE), had a Shākiriyya. We learn this from the tradition relating how he sent the poet 'Umāra

162 Al-Ṭabarī, Ta'rīkh, 3, 928: فنزلتها في عدة ممن ركب معي من خاصة ثقاتي وشاكريتي وصيرت عدة منهم فرسانا ورجالة بين باب خراسان والمشر عة و على الثط : De La Vaissière 2007, 157.

163 Cf. De La Vaissière 2007, 157, for a different interpretation of this evidence. We know that some of these soldiers spoke Persian and were also of non-Arabic origin, but it is hard to prove that they indeed comprised the Shākiriyya contingents. On Țāhir's army, see Elad 2010, esp. 37-40, 53-54, 61, 67f.; Elad 2013, esp. 246-264.

164 Ibn A'tham al-Kūfī, Kitāb al-Futūh (ed. Hyderabad), 7, 331: mentioned in a note by Shaban 1976, 2: 65, as proof that al-Shākiriyya were the mawālī of the ruler. There is no confirmation for this in the sources quoted by him; on the revolt, see al-Ṭabarī, Ta'rīkh, 3, 1101-1102 (no mention of al-Shākirdiyya, though). Al-'Alath is on the border of al-Jazīra-al- 'Irāq, see Yāqūt, Mu jam (Beirut ed.), 4, 145-146.

165 Steingass 1963, 724; see also Haim 1953, 486. 
b. 'Aqīl to Tamīm b. Khuzayma [b. Khāzim] al-Nahshalī al-Tamīmī'166 and then to the house of Khālid b. Yazīd b. Mazyad al-Shaybānī (Rabī'a) ${ }^{167}$ escorted by a Shākirī from his Shākiriyya.

\section{Al-Jāḥiẓ̣’s Opinion on al-Shākiriyya}

The Shäkiriyya's closeness to the regime and to the ruler is also emphasized by al-Jāhiz. As part of his discussion of the various components of the army of the caliphate he tries to diminish contradictions and differences as much as possible, and to stress what is equal and similar. As an example of this he compares al-Shākiriyya and the army (al-jund):

People think that since there is a difference in the form of the script and the pronunciation of the names of the (different) types of human race, that their character in reality and their (internal) meaning is also different in the same way. However, things are not like they think. For you will see that even if the name al-Shākiriyya is different in form and in pronunciation from (the word) al-jund, the internal meaning ( $\left.a l-m a^{\prime} n \bar{a}\right)$ respecting both is close to each other, for both stem from one meaning (one source) and one action...obedience to the caliphs and support of the regime. ${ }^{168}$

Al-Jāhiz knows, of course, the Shākiriyya's character; therefore he does not bother to explain it precisely to us. All he wants is to bridge the difference between this unit and the army. Through this explanation, we nevertheless understand that there is a difference and that this unit is not identical to the regular army regiments.

In another place al-Jāhịiz mentions al-Shākiriyya, evidently in the period of al-Mu'tașim or al-Wāthiq, but here too he does not clarify the character of this military unit. ${ }^{169}$ Relying on this text and on the previous text cited, 'Abd al-

166 The son of one of the most prominent commanders of $a l-A b n \bar{a}$. On his father and grandfather, see Crone 1980, 180ff. Tamīm is not mentioned by Crone.

167 Ibn Abī Ṭāhir Ṭayfūr, Kitāb Baghdād, 286-289; al-Ișfahānī, al-Aghānī (ed. Būlāq), 20, 186187: فبعث معي شاكريًا من شاكريته حتى وقف بي على باب تميم Ibn Ḥamdūn, Tadhkira, 2, 344f.; on Khālid b. Yazīd b. Mazyad, see Crone 1980, 170, to which the three sources quoted should be added. 168 Al-Jāḥiz, Manāqib al-Turk, 30.

169 Al- Jāhiz, al-Hayawān, 2, 130; al-Jāhị describes a dog that used to attack the hoofs of the horses of al-Shākiriyya which apparently accompanied Muhammad b. 'Abd al-Malik b. Abān b. Ḥamza, known as Ibn al-Zayyāt. When this occurred is not said, but Muhammad b. 'Abd al-Malik was a wazìr, first of al-Mu'tașim between 219-220 H/834-835 CE, then of al-Wāthiq (r. 227 H/842 CE-232 H/847 CE), and even for a short period in the first year of al-Mutawakkil's reign ( $233 \mathrm{H} /$ 847 CE), at the end of which he was executed. See Sourdel,"Ibn al-Zayyāt”, EI², 3, 974. Although 
Salām Hārūn claims that the term means a mercenary army and that al-al-Jāhịiz uses the word to denote an army.

\section{Conclusion}

\section{The Importance of the Study of the Shākiriyya}

In Islamic studies, controversies have emerged over the relation between the Shākiriyya institution and the Mamlūk system, the dominant military mode in medieval Islam. It has been the dominant view that the Shäkiriyya system is uniquely Islamic and indigenous to Islamic civilization (see the references here to Ayalon, Pipes, Crone, Bosworth and most recently Gordon, and the detailed discussion above). In the last few years a group of scholars has started to test the prevailing views on the origin of the system. Noteworthy is Shaban, who as early as 1976 argued that the chākar system stemmed from the Persian tradition. Other scholars (Beckwith, Yonggyu, De La Vaissière) argue for the Central Asian (Soghdian) origin of the institution of al-Shākiriyya.

Both Shaban and Beckwith, when referring to the Samarran period from alMu'tașim's rule on, identify the Shākiriyya regiments with the Turkish Shākiriyya units. De La Vaissière argues that the Shākiriyya was a distinct institution in the Soghdian army that made its way from Samarqand to Sāmarrā' ${ }^{170}$ Accepting Shaban's main argument (although arguing for a Central Asian origin and not a Sāsānian one as suggested by Shaban), De La Vaissière dedicates a long and exhaustive discussion in his book to the view that al-Mu'tașim organized his new army units according to the Central Asian pattern. Gordon strongly refuted this argument:

The arguments of Shaban and Beckwith [De La Vaissière's book was not yet published], which identify the Samarran Turkish guard with Iranian (Shaban) or Central Asian (Beckwith) use of the chākar institution, are to be rejected...the Turks and Shākiriyya of Samarra remained as entirely separate forces. ${ }^{171}$ [See the discussion above.]

it was not specifically stated that al-Shākiriyya rode immediately after or in front of the wazir Muhammad b. 'Abd al-Malik, it is possible that they constituted a kind of special personal guard.

170 De La Vaissière 2007, 59.

171 Gordon 2001, 40. 
Yonggyu and De La Vaissière argue that the Inner Asian and the 'Abbāsī institutions of the personal guard, as well as that of the Tang dynasty (618-907 CE), show similarities with the Shākiriyya. Their systems were based on a process geared to generate loyalty to the ruler within the personally attached servitor group. Thus, each system stressed the special individual relationship between the ruler and his personal servitors and guards.

As my limited study has shown, it is a difficult if not impossible task to judge where these similarities came from. Do the correlations stem from origin, or are they (as Yonggyu argued ${ }^{172}$ ) an indication that peoples of different regions happened to share similar political needs and consequently had similar institutions that evolved separately and indigenously? Even if the Turkish/Central Asian tradition was an influence, due to the different socio-cultural contexts we can expect that each region's system developed in a way uniquely compatible and acceptable to the pre-existing cultural norms of the host society. When we gauge the degree of possible influence coming from the steppe tradition of personal guards, it is also important to inquire to what extent and in what ways the institutions Turks carried from their life in the steppe interacted with pre-existing social norms.

I started this research when I came upon the evidence of al-Shākiriyya units in al-Ma'mūn's army, hoping to gain a better understanding of this term or institution. It seems that the relatively large amount of evidence available from the Umawī and the early 'Abbāsī periods are still too limited to fully demonstrate that a) the Shākiriyya units denote Turks and b) that these allegedly Turkish units performed their service for the 'Abbāsī caliphs according to concepts and practices from the Central Asian steppe.

As already stated above, from the little on the Shäkiriyya in the Arabic sources we can discern a distinct military character. Its other characteristics are difficult to understand. A number of army commanders in the Umawi period are known to have had Shäkiriyya. All of them (except two, B/1 and B/6), took part in the Transoxanian campaigns, and the Shäkiriyya units that are mentioned are thus connected to Central Asia. We do not know the size of these units and whether they were incorporated within the Umawī army in al-'Irāq. In some cases, when the term Shākiri appears in the sources it does not seem to have a military connection or connotation. Sometimes it can be rendered as a loyal adherent or even a servant $(\mathrm{B} / 6$ and $\mathrm{B} / 16)$; in other cases it is equivocal $(\mathrm{B} / 12, \mathrm{~B} / 14$ and $\mathrm{B} / 17)$.

172 Yonggyu 2004, 34. 
During the early 'Abbāsī period (the reigns of al-Saffāh until al-Ma'mūn), except for two cases in which the term unequivocally denotes a military unit, the few other texts are ambiguous and equivocal (C/1, C/3, C/4, C/5 and C/6); in several cases a servant or non-military person or unit is alluded to $(C / 3, C / 7, C / 9$ and $\mathrm{C} / 10)$. As to the military units $(\mathrm{C} / 2$ and $\mathrm{C} / 8)$, the last piece of evidence $(\mathrm{C} / 8)$ is unique: the long and detailed description of the clothes, fine objects, weapons and so forth found in Hārūn al-Rashīd's store houses (الخزائن) upon al-Amīn's ascendance to the caliphate. Among the weapons he mentions " 50,000 swords of (for?) the Shākiriyya and the slaves (الغلمان)".

This brings us to al-Ma'mūn's reign. From the few pieces of evidence at our disposal, it is clear that al-Ma'mūn already had military units in Khurāsān named al-Shākiriyya. This Shākiriyya had a high status in al-Ma'mūn's court. It is most plausible that this unit consisted of non-Arabs. It seems that this caliph's army also included Shākiriyya units in al-'Irāq. The size of these Shākiriyya units is not attested by the sources. At least in Khurāsān, it seems that the size of this unit was not big.

Two of al-Ma'mūn's senior commanders, Țāhir b. al-Ḥusayn and his relative 'Alī b. Hishām, had Shākiriyya military units. Țāhir's Shākiriyya is mentioned together with his closest and most loyal adherents, and it is possible that the intent here is to describe a kind of personal select guard, perhaps-though there is no proof of this-connected by ties of walā' or even servitude to Țāhir. The closeness of the Shākiriyya to the regime and its ruler is also emphasized by al-Jāhiz, but even he does not provide any information regarding their ethnicity and origin. The sources checked provide no information on the ethnic composition, mobilization or military training of the Shäkiriyya, or the possible ties between the commander/master and his Shākir.

In later periods, we find al-Shākiriyya mentioned more frequently from 227 H/842 CE (the period of al-Wāthiq's rule) and particularly during al-Mutawakkil's reign (232 H/247 $847 \mathrm{CE}-861 \mathrm{CE}$ ) and onwards (dozens of times), until the year $266 \mathrm{H} / 880 \mathrm{CE}$ (the reign of al-Mu'tamid 'alā Allāh, d. $279 \mathrm{H} / 892 \mathrm{CE}$ ), when this unit is no longer mentioned by al-Tabarī. Al-Shākiriyya in this period is beyond the scope of this article. No comprehensive study has yet been made of the 'Abbāsī army after the period of al-Ma'mūn's reign. ${ }^{173}$

173 The most up-to-date study, mainly based on the Arabic sources, is Gordon's; useful comments with historical insight are rendered by Kennedy 1981; Shākiriyya are also mentioned (without analysis) by Amabe 1995, 141, 147, 155-161, 255; for the term Shākiriyya in the Sāmarrān period one should consult several volumes of al-Ṭabarīs History in translation, esp. vols. 34-36 (indexes), which will enable thorough checking of the Arabic text. However, in order to conduct a broad study of the term and institution, all the possible Arabic sources must be examined. This 
In my previous articles ${ }^{174}$ I argued against the accepted view in research which claims that from its foundation, the 'Abbāsī caliphate is distinguished by the decisive influence of non-Arab elements, and that this influence increases rapidly and is already obvious at the time of the caliph al-Mahdī (r. $158 \mathrm{H} / 775$ CE-169 H/785 CE). ${ }^{175}$ Al-Ma'mūn's reign (198 H/813 CE-218 H/833 CE) is considered by all scholars to be the peak of the non-Arab (mainly Iranian) penetration of the caliphate, especially in the army. Students of the period of al-Ma'mūn's reign are united in the opinion that the major part of his army was composed of non-Arab Khurāsānīs, mainly of Iranian origin. ${ }^{176}$ However,

[s]crutiny of the political and social background in Khurāsān under al-Ma'mūn's rule reveals... that this description of al-Ma'mūn's armies and commanders is imprecise and one-dimensional. An examination of this army, its mobilization, consolidation and battles, from al-Ma'mūn's arrival in Marw in 193/809 until his death in 218/833, provokes interesting conclusions that transform the accepted picture of al-Ma'mūn's activity in Khurāsān and of the characteristics of the armies he raised in this province. ${ }^{177}$...In all probability, al-Ma'mūn's army included non-Arab units, called 'Ajam or 'Ajam Ahl Khurāsan, but references to them are very few. We have not found evidence of massive mobilization of non-Arab soldiers from Khurāsān or beyond it, in Transoxania. ${ }^{178}$

Two pieces of evidence bear witness to relatively large non-Arab units in al-Ma'mūn's army. The first refers to the non-Arab units in Țāhir b. al-Ḥusayn's army, units of Turks, Bukhārīs and Khwārizmīs. ${ }^{179}$ From the second we learn of units

is possible to a large extent due to the extensive repository of Arabic literature recorded on compact discs (such as the al-Turāth CDs, Ahl al-Bayt and al-Maktaba al-Shāmila), containing many thousands of books from different genres of Arabic literature (hadìth, adab, fatāwā, fiqh, sìra, Qur'ān, tafsìr, geography, biography, poetry and more) now at our disposal for the first time. 174 Elad 1995; Elad 2005, esp. 317-320.

175 Ayalon 1994, 2-4, 35-36 and the important information in the addenda; Crone 1980, 68 and esp. 74; Kennedy 1981, 102-103; Elad 1995, 118-119.

176 For a discussion and bibliography, see Elad 2005, 317, n. 151; Elad 2013, 279, nn. 272, 273; add De La Vaissière 2007, 151ff.

177 Elad 2005; the quotation is from 317; and see also Elad 2010 and 2013; see De La Vaissière 2007, 150ff. for a different interpretation; for two more examples cf. Elad, 2005, 295-316 (the long text in al-Ṭabarī, Ta'rīkh, 3, 773-774: al-Ma'mūn's appeal to the Arab tribes in Khurāsān) and Elad 2010, 49-50 (in regard to the recruitment of non-Arab contingents by al-Ma'mūn), mainly according to al-Balādhurī, Futūh, 430-431 (de Goeje’s ed.; ed. al-Ṭabbā', 606): to De La Vaissière's analysis and arguments in De La Vaissière 2007, 152.

178 Elad 2005, the quotation is from 318; and cf. De La Vaissière 2007, 152.

179 Turks: al-Ṭabarī, Ta'rīkh, 3, 799; Khwārizmīs: ibid., 801: at least 700 soldiers [!]; al-Mas'ū ūī, Murūj, 4, 263; al-Bukhāriyya: al-Ṭabarī, Ta'rīkh, 3, 800, 802; the important and unique tradition in al-Ṭabarī is related from Aḥmad b. Hishām, who was most probably the cousin of Ṭāhir b. al- 
of slave soldiers (ghulām; atrāk), most of whom were already purchased by al$\mathrm{Mu}$ 'tașim already during his brother's reign. They numbered between 3,000 to 4,000 soldiers. ${ }^{180}$ In $213 \mathrm{H} / 828 \mathrm{CE}$ a slave regiment of 4,000 soldiers is mentioned in al-Mu'tașim's army in Egypt. This is the first time that a slave military unit on such a large scale is mentioned. ${ }^{181}$ The Shākiriyya units in al-Ma'mūn's army mentioned above most probably bear witness to additional non-Arab recruits from Khurāsān (Transoxania?).

What is the reason for this far-reaching research pattern regarding the nonArab makeup of al-Ma'mūn's army? It seems the mere fact that al-Ma'mūn lived in Khurāsān and chose it as the centre for his governorship, was sufficient for scholars to argue in favour of this thesis. It is possible that this view developed, at least in the case of Tāhir b. al-Husayn, given the fact that the army he fielded against 'Alī b. 'Īsā included non-Arab units (this is, as noted above, a rare evidence).

Nonetheless, none of al-Ma'mūn's senior commanders can be considered as belonging to a new non-Arab Khurāsānī army. It is clear that $a l-A b n \bar{a}^{\prime}$ forces and their commanders who joined al-Ma'mūn's army cannot be included in the new non-Arab Khurāsānī army. ${ }^{182}$ The picture is not one-dimensional. But the many reports that Arab political and military power had not completely disappeared in various regions of the caliphate; that al-Ma'mūn was required to take them into consideration and to use them as a military force which he mobilized for battle in the different parts of the caliphate; and that the tribal make-up of this or that area often dictated the caliph's policy ${ }^{183}$ all cannot hide the clear

Ḥusayn (see Elad 2010, 39); he was șāhib al-shurța of Țāhir's camp (see al-Ṭabarī, Ta'rīkh, 3, 799802; according to al-Mas' 'ùdī, Murūj, 4, 263-265, he is one of the senior commanders (min wujūh al-quwwād)); he is also mentioned as one of the commanders of al-Ma'mūn and al-Mu'tașim (Elad 2010, 39).

180 Al-Ya'qūbī, Buldān, 256: زهاء ثلاثة آلاف غلام; al-Kindī, Wulāt, 212: في أربعة آلاف من أنراكه; Ayalon 1994, 26; Ismā̄il 1996, 14; Pipes 1981, 146-147; Lassner 1980, 113; Kennedy 1981, 167; Elad 2005, 318; De La Vaissière 2007, 155; but esp. Gordon 2001, $16 \mathrm{ff}$.

181 Al-Kindī, Wulāt, 212 (I follow the accepted rendering of the word atrāk as slaves); Pipes 1981, 51; Lassner 1980, 113; Kennedy 1981, 167; but cf. the careful rendering of Gordon 2001, 16: Turks.

182 Elad 2005, 283ff. (al-Abnä’), but especially Elad 2010 and 2013.

183 For examples, see 1) al-Jazīra: al-Azdī, Ta’rīkh al-Mawșil, 326-327: year 196 H/811-812 CE; ibid., 332-333; Ibn al-Athīr, al-Kāmil, 6, 300-301: year 198 H/808-809 CE; al-Azdī, Ta'rīkh alMawșil, 332, the same year: Țāhir b. al-Ḥusayn’s leniency and favourism towards the southern tribes in Mosul; ibid., 336-337; Ibn al-Athīr, al-Kämil, 6, 317: year 199 H; al-Azdī, Ta'rīkh al-Mawșil, 343-348; Ibn al-Athīr, al-Kāmil, 6, 349: year 202 H/817-818 CE; ibid., 350: in the same year alMa'mūn bluntly interferes in the tribal feuds in Mosul; for other examples for tribal feuds in Mosul during al-Ma'mūn's reign, see al-Azdī, Ta’rīkh al-Mawșil, 359-360: year 206 H/821-822 
waning of Arab power in the 'Abbāsī caliphate, which reached its highest point in the days of al-Mu'tașim. ${ }^{184}$ They do, however, show that this process was a slow and complex one.

\section{Appendix}

\section{The Term Shākirī in the Meaning of Servant/Attendant from the Middle to the End of the $9^{\text {th }}$ Century.}

A. Two of the imāms of the Shī'a (al-Ithnā 'Ashariyya), are described as having a Shākirī. The first is Mūsā (al-Kāẓim) b. Ja'far al-Ṣādiq (d. 183 H/799 CE), who is described as riding escorted by a Shākirī (راكب ومعه شاكري). The second is al-Ḥasan (al-'Askarī) b. 'Alī b. Muḥammad al-Jawwād (d. 260 H/874 CE). A Shākirī of his (شاكري لمو لانا أبي محمد الحسن بن علي), called Abū 'Abdallāh Muhammad al-Shākirī, relates some anecdotes about his master (ustādhī). ${ }^{185}$

CE; 365-366: year 208 H/823-824 CE; 371: year 210/825-826; 373: year 211 H/826-827 CE; 422-423: year 219 H/834-835 CE (al-Mu'tașim's reign); 378, 380-382,386-394 (years 212-213 H/827-829 $\mathrm{CE}$ ): the army and Arab commanders of Muhammad b. Ḥumayd b. 'Abd al-Ḥamīd, see discussion in Elad 2013, 272-275); Diyār Bakr and the surroundings of al-Raqqa (the rebellion of Nașr b. Shabath), see Kennedy 1981, 169-170; al-Ya'qūbī, Ta'rīkh, 2, 540; Ibn al-Athīr, alKāmil, 6, 303-304: year 198 H/813 CE; Armenia and Ādharbayjān: al-Ya'qūbī, Ta'rīkh, 2, 566; al-Azdī, Ta'rīkh al-Mawșil, 384: year 212 H/827-828 CE; al-Ṭabarī, Ta'rīkh, 3, 1112: year 212 H/ 827-828 CE; 2) al- 'Irāq: al- Daskara's vicinity (50 miles north of Baghdād): al-Azdī, Ta'rīkh alMawșil, 364; Ibn al-Athīr, al-Kāmil, 6, 385; al-Kūfa and its vicinity: al-Ṭabarī, Ta'rīkh, 3, 956, 977; al-Khatị̄b al-Baghdādī, Ta'rīkh, 12, 413; al-Ṭabarī, Ta’rīkh, 3, 1019, 1022: year 202 H/817818 CE [= Crone 1980, 110-111]; al-Bașra: for the Muhallabī family in the city, see Crone 1980, 135; add al-Ișfahānī, al-Aghānī, 17, 46 (Būlāq ed.) [Dār al-Kutub ed., 18, 24] to her bibliography; correct Crone 1980, 135, Dāwūd b. Bishr to Dāwūd b. Yazīd; see also, al-Ya'qūbī, Ta'rīkh, 2, 557558: Muhammad b. 'Abbād al-Muhallabī, who is defined as: وكان سيد أهل البصرة في زمانه; Ibn Ḥazm, Jamhara, 369: وكان سيدا; add him to Crone’s biographies of the family; al-Iṣfahānī, al-Aghānì (Būlāq ed.), 18, 19-20, 60 [=Dār al-Kutub ed., 20, 99-101; Ibn Hazm, Jamhara, 369, 370: the poet Ibn Abī 'Uyayna al-Muhallabī and his strong satire against the northern tribes; Ibn Khayyāț, Ta'rīkh, 384; al-Ṭabarī, Ta'rīkh, 3, 1144-1145: Banū Tamīm in al-Bașra; Baghdād: alIṣfahānī, al-Aghānī (Būlāq ed.), 18, 29, 51, 53, 54, 60 [=Dār al-Kutub ed., 20, 120, 166-167, 170, 172, 186]; al-Azdī, Ta'rīkh al-Mawșil, 239, 354; Ibn Abī Țāhir Țayfūr, Kitāb Baghdād, 286-289; al-Ișfahānī, al-Aghānī (ed. Būlāq), 18, 186-187; for socio-cultural examples of the period, e.g. the Arab socio-cultural supremacy and Arabism that continued well into the early 'Abbāsĩ caliphate with an emphasis on al-Ma'mūn's reign, see Elad 2005, 118-127.

184 Ayalon 1994, 21-22; Kennedy 1981, 165; Pipes 1981, 150.

185 Mūsā al-Kāzim: al-Ṭūsī, Ikhtiyār, 2, 735-736; al-Rāwandī, al-Kharā’ij, 2, 327; al-Irbilī, Kashf al-Ghumma, 3, 43: وخلفه شاكري ; al-Ḥasan b. 'Alī: al-Ṭabarī (al-Imāmī), Dalā'il al-Imāma, 429-430. 
B. In his epistle “An Answer against the Christians," al-Jāhịiz remarks: We have known them (the Christians) to possess hackneys of mixed breed and excellent swift horses; they congregate in big crowds and play with the curved sticks [while on horseback]; and they feign [to be dignified Arabs] by donning al-Madīnī dress [وتحذفوا المديني] and are dressed in [clothes made of the kind of cloth called] mulham and in clothes inlaid with precious stones (muțabbaqa); and they possess al-Shākiriyya, and they call themselves al-Ḥasan and al-Ḥusayn and al-'Abbās, Fạ̣l and 'Alī...' ${ }^{186}$

\section{Bibliography}

\section{Primary Sources}

Abū Nu'aym, Aḥmad b. 'Abdallāh al-Ișfahānī (1933-38), Ḥilyat al-awliyā' wa-țabaqāt al-așfiyā', Cairo: Maktabat al-khanānjī.

Anonymous (1971), Akhbār al-dawla al-'Abbāsiyya wa-fīhi akhbār al-'Abbās wa-wuldihi, edited by 'Abd al-'Azīz al-Dūrī and 'Abd al-Jabbār al-Muțțalibī, Beirut: Dār șādir.

al-'Askarī, al-Ḥasan b. 'Abdallāh b. Sa'īd b. Ismā'īl (1402 H), Tașhīfāt al-muhaddithīn, edited by Maḥmūd Aḥmad Mīra, Cairo: al-Mațba'a al-'arabiyya al-ḥadītha.

'Awwād, Mikhā’îl (1384/1964), Nuṣuṣ ḍā'i'a min kitāb al-wuzarā' wa-l-kuttāb li-Muhammad

b. 'Abdūs al-Jahshiyārī, Beirut: Dār al-kitāb al-lubnānī.

al-Azdī, Abū Zakariyyā' Yazīd b. Muḥammad b. Iyyās (1387/1967), Ta'rīkh al-Mawṣil, edited by 'Alī Ḥabīiba, Cairo.

al-Balādhurī, Aḥmad b. Yaḥyā (1417/1996), Ansāb al-ashrāf, edited by Suhayl Zakkār and Riyāọ Ziriklī, Beirut: Dār al-fikr li-l-țibā'a wa-l-nashr wa-l-tawzī‘

al-Balādhurī, Ạ̣mad b. Yaḥyā (1866), Kitāb Futūḥ al-buldān, edited by M. J. de Goeje, Leiden: Brill.

al-Balādhurī, Aḥmad b. Yaḥyā (1407/1987), Kitāb Futūḥ al-buldān, edited by 'Abdallāh Anīs al-Ṭabbā' and 'Umar Anīs al-Ṭabbā', Beirut: Mu'assasat al-ma'ārif li-l-țibā'a wa-l-nashr. al-Bayhaqī, Ibrāhīm b. Muḥammad (1961?), al-Mahāsin wa-l-masāwī, edited by Muhammad Abū l-Fạ̣l Ibrāhīm, Cairo: Dār al-ma'ārif.

al-Bukhārī, Muḥammad b. Ismā'īl (n.d.), al-Ta'rīkh al-kabīr, edited by Hāshim al-Nadwī, [Beirut?]: Dār al-fikr.

al-Dhahabī, Muḥammad b. Aḥmad Shams al-Dīn (1416/1995), Mīzān al-ítidāl fĩ naqd al-rijāl, edited by 'Alī Muḥammad Mu'awwạ̣ and 'Ādil Aḥmad 'Abd al-Mawjūd, Beirut: Dār al-kutub al-ilmiyya.

al-Dhahabī, Muḥammad b. Aḥmad Shams al-Dīn (1982-85), Siyar a'lām al-nubalā', Beirut: Mu'assasat al-risāla.

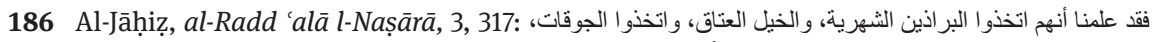

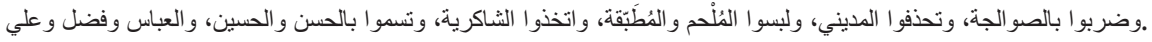


al-Dhahabī, Muḥammad b. Aḥmad Shams al-Dīn (1408-21/1988-2000), Ta'rīkh al-Islām wa-țabaqāt al-mashāhīr wa-l-a'lām, edited by 'Umar 'Abd al-Salām Tadmurī, Beirut: Dār al-kitāb al-'arabī.

al-Dīnawarī, Abū Ḥanīfa Aḥmad b. Dāwūd (1960), Kitāb al-Akhbār al-ṭiwāl, edited by 'Abd al-Mun 'im 'Āmir, Cairo: Dār iḥyā' al-kutub al-'arabiyya.

al-Ghazūlī, 'Alī b. 'Abdallāh al-Bahā'ī (1426/2006), Mațāli' al-budūr fĩ manāzil al-surūr, Cairo: Maktabat al-thaqāfa al-dīniyya.

Ḥājjī Khalīfa, Mușțafā b. 'Abdallāh (1413/1992), Kashf al-ẓunūn 'an asāmī l-kutub wa-l-funūn, Beirut: Dār al-kutub al-'ilmiyya.

al-Ḥamawī, Abū Bakr b. 'Alī b. Muḥammad (1971), Thamarāt al-awrāq, edited by Muḥammad Abū l-Faḍl Ibrāhīm, Cairo: Maktabat al-khānjī.

al-Ḥillī, Abū l-Baqā' Hibbat Allāh (1404/1984?), al-Manāqib al-mazyadiyya fĩ akhbār al-mulūk al-Asadiyya, edited by Șālị̣ Mūsā Darādika and Muḥammad 'Abd al-Qādir Khuraysāt, Amman: Maktabat al-risāla al-ḥadītha.

Ibn Abī Ṭāhir Ṭayfūr (1908), [al-Juz' al-sādis min] Kitāb Baghdād, edited by H. Keller, Leipzig. Ibn al-'Adīm, 'Umar b. Aḥmad (1986-90), Bughyat al-țalab fĩ ta'rīkh Ḥalab, edited by F. Sezgin, Frankfurt: Ma'had ta'rīkh al-'ulūm al-'arabiyya wa-l-islāmiyya.

Ibn al-'Adīm, 'Umar b. Aḥmad (1408/1988), Bughyat al-țalab fĩ ta'rīkh Ḥalab, edited by Suhayl Zakkār, Damascus: Mațābi' dār al-ba'th.

Ibn al-'Arabī, Muḥammad b. 'Alī (n.d.), al-Futūḥāt al-makiyya, Beirut: Dār șādir.

Ibn 'Asākir, Abū l-Qāsim 'Alī b. al-Ḥasan (1415-20/1995-2001), Ta'rīkh Madīnat Dimashq, edited by 'Umar b. Gharāma al-'Amr(aw)ī, Beirut: Dār al-fikr.

Ibn A'tham al-Kūfī, Aḥmad Abū Muḥammad (1388-95/1968-75), Kitāb al-Futūḥ, Hyderabad: Dā'irat al-ma'ārif al-'uthmāniyya.

Ibn A'tham al-Kūfī, Aḥmad Abū Muḥammad (1406/1986), Kitāb al-Futūḥ, Beirut: Dār al-kutub al-'ilmiyya.

Ibn al-Athīr, 'Izz al-Dīn 'Alī b. Muḥammad (1402/1982), al-Kāmil fī l-ta'rīkh, Beirut: Dār șādir/Dār Beirut.

Ibn al-Athīr, 'Izz al-Dīn 'Alī b. Muḥammad (n.d.), Usd al-ghāba fĩ ma'rifat al-șaḥāba, Beirut: Dār al-kitāb al-'arabī.

Ibn Bābūyh al-Qummī, Muḥammad b. 'Alī b. al-Ḥusayn b. Mūsā (1390/1970), 'Uyūn akhbār al-Riẹā, al-Najaf.

Ibn Bābūyh al-Qummī, Muḥammad b. 'Alī b. al-Ḥusayn b. Mūsā (1404/1984), 'Uyūn akhbār al-Rị̣ā, edited by Ḥusayn al-A'lamī, Beirut: Mu'assasat al-a'lamī li-l-maṭbū'āt.

Ibn al-Faqīh, Aḥmad b. Ibrāhīm al-Hamdhānī (1885), Mukhtașar kitāb al-buldān, edited by M.J. De Goeje, Leiden: Brill.

Ibn Abī l-Ḥadīd, Abū Ḥāmid 'Abd al-Ḥamīd b. Hibat Allāh b. Muḥammad (1959-64), Sharh nahj al-balāgha, edited by Muḥammad Abū l-Faḍl Ibrāhīm, Cairo: Mușțafā al-Bābī al-Ḥalabī.

Ibn Ḥajar al-'Asqalānī, Aḥmad b. 'Alī Shihāb al-Dīn Abū l-Faḍl (1972; repr. 1992), al-Iṣāba fĩ tamyīz al-ṣaḥāba, edited by 'Alī Muḥammad al-Bijāwī, Cairo: Dār nahụat Miṣr li-l-țab' wa-l-nashr (repr. Beirut: Dār al-jīl).

Ibn Ḥajar al-'Asqalānī, Ạ̣mad b. 'Alī Shihāb al-Dīn Abū l-Faḍl (1404/1984), Tahdhīb al-tahdhīb, Beirut: Dār al-fikr.

Ibn Ḥamdūn, Muḥammad b. al-Ḥasan b. Muḥammad b. 'Alī (1417 H), al-Tadhkira al-Ḥamdūniyya, edited by lṇsān 'Abbās, Beirut: Dār șādir. 
Ibn Abī Ḥātim, 'Abd al-Raḥmān b. Muḥammad b. Idrīs al-Tamīmī al-Rāzĩ (1371-73/1952-53), Kitāb al-Jarh wa-l-ta'dīl, Beirut: Dār iḥyā' al-turāth al-'arabī.

Ibn Ḥazm, 'Alī b. Aḥmad b. Sa'īd (1962), Jamharat ansāb al-'Arab, edited by 'Abd al-Salām Muḥammad Hārūn, Cairo: Dār al-ma'ārif.

Ibn Ḥibbān, Muḥammad Abū Ḥātim al-Bustī al-Tamīmī (1393-1403/1973-83; photocopy: 1395/1975), Kitāb al-Thiqāt, Hyderabad: Dā'irat al-ma'ārif al-'uthmāniyya (photocopy: edited by Sharaf al-Dīn Ạ̣mad, Beirut: Dār al-fikr).

Ibn Ḥibbān, Muḥammad Abū Ḥātim al-Bustī al-Tamīmī (1395-1412/1975-92), Kitāb al-Majrūhīn min al-muḥaddithīn al-ḍu'afä' wa-l-matrūkīn, edited by Mạ̣mūd Ibrāhīm Zāyid, Aleppo: Dār al-wa'y.

Ibn Ḥibbān, Muḥammad Abū Ḥātim al-Bustī al-Tamīmī (1412/1992), Ṭabaqāt al-muḥaddithīn bi-Ișfahān, Beirut: Mu'assasat al-risāla.

Ibn al-'Imrānī, Muḥammad b. 'Alī b. Muḥammad (1420/2001), al-Inbā' fĩ ta'rīkh al-khulafā', edited by Qāsim al-Sāmarrā'î, Cairo: Dār al-āfāq al-'arabiyya.

Ibn al-Jawzī, 'Abd al-Raḥmān b. 'Alī b. Muḥammad Abū l-Faraj (1399/1979), Șafwat al-Ṣafwa, edited by Maḥmūd Fākhūrī and Muḥammad Rawās Qal'ajī, Beirut: Dār al-Ma'rifa.

Ibn al-Jawzī, 'Abd al-Raḥmān b. 'Alī b. Muḥammad Abū l-Faraj (1412/1992), al-Muntaẓam fī ta'rīkh al-mulūk wa-l-umam, edited by Muḥammad Mușțafā 'Abd al-Qādir 'Ațā, Beirut: Dār al-kutub al-ilmiyya.

Ibn al-Kalbī, Hishām b. Muḥammad b. al-Sā’ib (1407/1986), Jamharat al-nasab, edited by Nājī Ḥasan, Beirut: 'Ālam al-kutub.

Ibn al-Kalbī, Hishām b. Muḥammad b. al-Sā'ib (1408/1988), Nasab Ma'add wa-l-Yaman al-kabīr, edited by Nājī Ḥasan, Beirut: 'Ālam al-kutub/Maktabat al-nahḍa al-'arabiyya.

Ibn Kathīr, Abū l-Fidā' Ismā'īl b. 'Umar (1408/1988), al-Bidāya wa-l-nihāya fí l-ta'rīkh, edited by 'Alī Shīrī, Beirut: Dār ị̣yā' al-turāth al-'arabī.

Ibn Khallikān, Aḥmad b. Muḥammad b. Ibrāhīm (1969), Wafayāt al-a'yān wa-anbā' abnā' al-zamān, edited by lḥsān 'Abbās, Beirut: Dār al-thaqāfa.

Ibn Khayyāț, Khalīfa al-'Ușfurī (1386/1967), Ta'rīkh, edited by Akram Ḍiyā' al-'Umarī, Najaf: Mațba'at al-ādāb.

Ibn Mākūlā, 'Alī b. Hibat Allāh (1381-86/1962-67), al-lkmāl fĩ raf' al-irtiyāb 'an al-mu'talif wa-l-mukhtalif min al-asmā' wa-l-kunā wa-l-ansāb, vols. 1-6, edited by 'Abd al-Raḥmān b. Yahyyā al-Mu'allimī, Hyderabad: Dā'irat al-ma'ārif al-'uthmāniyya.

Ibn Mākūlā, 'Alī b. Hibat Allāh (1411/1990), al-lkmāl fĩ raf' al-irtiyāb 'an al-mu'talif wa-l-mukhtalif min al-asmā' wa-l-kunā wa-l-ansāb, vol. 7, Beirut: Dār al-kutub al-ilmiyya.

Ibn Manz̦ūr, Muḥammad b. Mukarram (1404-11/1984-90), Mukhtaṣar ta'rīkh madīnat Dimashq, Damascus: Dār al-fikr li-l-ṭibā'a wa-l-nashr wa-l-tawzī' .

Ibn Munqidh, Usāma b. Murshid b. 'Alī b. Muqallad (1407/1987), Lubāb al-ādāb, edited by Aḥmad Muḥammad Shākir, Cairo: Mațba'at al-sunna.

Ibn al-Nadīm, Abū l-Faraj Muḥammad b. Isḥāq (1971), al-Fihrist, edited by Riḍā Tajaddud, Tehran.

Ibn Qutayba, Muslim b. Qutayba (1346/1928), Kitāb al-'Uyūn wa-l-akhbār, Cairo: Dār al-kutub.

(Pseudo) Ibn Qutayba, Muslim b. Qutayba (1388/1969), al-Imāma wa-l-siyāsa, Cairo: Mațba'at Mūsā al-Bābī al-Ḥalabī. 
Ibn Taghrībirdī, Jamāl al-Dīn Abū l-Maḥāsin Yūsuf (1348/1929), al-Nujūm al-zāhira fĩ mulūk Mișr wa-l-Qāhira, Cairo: Dār al-kutub.

Ibn Abī Ușaybi'a, Aḥmad b. al-Qāsim b. Khalīfa al-Anșārī (1967), 'Uyūn al- anbāà fī țabaqāt al-aṭibbā', edited by Nizār Rị̣ā, Beirut: Dār maktabat al-ḥayāt.

Ibn al-Wardī, 'Umar Abū Ḥafș (1358/1939), Kharīdat al-'ajā'ib wa-farīdat al-gharā'ib, Cairo: Mațba'at Muṣțafā al-Bābī al-Ḥalabī.

Ibn al-Zubayr, al-Rashīd (1959), Kitāb al-Dhakhā’ir wa-l-tuḥaf, edited by Muḥammad Ḥamīdullāh, Kuwait: Dā'irat al-mațbū'āt wa-l-nashr.

al-Irbilī, 'Alī b. 'T̄sā b. Abī l-Fatḥ (1405/1985), Kashf al-ghumma fī ma'rifat al-a'imma, Beirut: Dār al-aḍwā'.

al-Iṣfahānī, Abū l-Faraj 'Alī b. al-Ḥusayn b. Muḥammad (1284-85 H), Kitāb al-Aghānī, Būlāq. al-Ișfahānī, Abū l-Faraj 'Alī b. al-Ḥusayn b. Muḥammad (1345-81/1927-61), Kitāb al-Aghānī, vols. 1-16, edited by 'Alī al-Najīi Nāșif, Cairo: Dār al-kutub al-mișriyya.

al-Iṣfahānī, Abū l-Faraj 'Alī b. al-Ḥusayn b. Muḥammad (1389-94/1970-74), Kitāb al-Aghānī, vols. 17-24, edited by Ibrāhīm al-Abyārī, Cairo: al-Hay’a al-mișriyya al-'āmma li-l-ta'līf wa-l-kitāb.

al-Ișfahānī, Abū l-Faraj 'Alī b. al-Ḥusayn b. Muḥammad (1394-99/1974-79), Kitāb al-Aghānī, vols. 25-30, Cairo: Dār al-sha'b.

al-Jāḥiẓ, 'Amr b. Baḥr (1350/1932), al-Maḥāsin wa-l-ạ̣dād, Cairo: al-Maktaba al-tijāriyya.

al-Jāḥiẓ, 'Amr b. Baḥr (1356/1938), Kitāb al-Ḥayawān, edited by 'Abd al-Salām Hārūn, Cairo.

al-Jāḥiẓ, 'Amr b. Baḥr (1384/1964), "Manāqib al-Turk. Risāla ilā l-Fatḥ b. Khāqān fī manāqiib al-Turk wa-'āmat jund al-khilāfa”, in: 'Abd al-Salām Hārūn, ed., Rasā'il al-Jāḥiẓ, Cairo, 186.

al-Jāḥiẓ, 'Amr b. Baḥr (1388/1968), al-Bayān wa-l-Tabyīn, Cairo: Maktabat al-khānjī.

al-Jāḥiẓ, 'Amr b. Baḥr (1399/1979), al-Radd 'alā l-nașārā, edited by 'Abd al-Salām Muḥammad Hārūn, Cairo: Maktabat al-khānjī.

Jarīr wa-Farazdaq (1908-12), Naqā’id, edited by A. A. Bevan, Leiden: Brill.

Kaḥ̣̂ala, 'Umar Riḍā (1957-61, repr: 1993?), Mu'jam al-mu'allifīn, Damascus: al-Maktaba al-'arabiyya (repr. Beirut: Dār iḥyā' al-turāth al-'arabī).

al-Khațīb al-Baghdādī, Aḥmad b. 'Alī b. Thābit Abū Bakr (1417/1997), Ta'rīkh Baghdād, edited by Muștafā 'Abd al-Qādir 'Ațā, Beirut: Dār al-kutub al-'ilmiyya.

al-Kindī, Muḥammad b. Yūsuf (1379/1959), Wulāt Miṣr, edited by Ḥusayn Nașșār. Beirut: Dār Beirut/Dār șādir.

al-Majlisī, Muḥammad Bāqir (1403/1983), Biḥār al-anwār, Beirut: Mu’assasat al-wafā'/Dār iḥyā' al-turāth al-'arabī.

al-Marzubānī, Abū 'Ubaydallāh Muḥammad b. 'Imrān (1964), Nūr al-qabas al-mukhtașar min al-muqtabas fĩ akhbār al-nuhāt wa-l-udabā' wa-l-shu'arā' wa-l-'ulamā', abridged by Abū l-Maḥāsin Yūsuf b. Aḥmad b. Maḥmūd al-Yaghmūrī, edited by R. Sellheim, Wiesbaden: Franz Steiner.

al-Mas'ūdī, 'Alī b. al-Ḥasan b. 'Alī Abū l-Ḥasan (1894), Kitāb al-Tanbīh wa-l-ishrāf, edited by M. J. de Goeje. Leiden: Brill.

al-Mas'ūdī, 'Alī b. al-Ḥasan b. 'Alī Abū l-Ḥasan (1966-79), Murūj al-dhahab wa-ma'ādin al-jawhar, edited by Charles Pellat, Beirut.

al-Maymanī, 'Abd al-'Azīz (1354/1935), Simṭ al-la'ālī fĩ sharh Amālī al-Qālī. Vol. III: Dhayl al-la'ālī fĩ sharḥ dhayl Amālī al-Qālī, Cairo: Mațba'at lajnat al-ta'līf wa-l-tarjama wa-l-nashr. 
Miskawayh, Aḥmad b. Muḥammad b. Ya'qūb (n.d.), Tajārib al-umam wa-ta'āqub al-himam, edited by Abū l-Qāsim Imāmī, Tehran.

al-Mizzī, Jamāl al-Dīn Abū l-Ḥajjāj Yūsuf (1985-92), Tahdhīb al-kamāl fĩ asmā' al-rijāal, edited by Bashshār 'Awwād Ma'rūf, Beirut: Mu'assasat al-risāla.

al-Mu'āfā b. Zakariyyā' al-Nahrawānī, (1407/1987), al-Jalīs al-șālị̣ al-kāfĩ wa-l-anīs al-nāṣị al-shāfí, edited by lḥsān 'Abbās, Beirut: 'Ālam al-kutub.

al-Muțahhar b. Ṭāhir al-Maqdisī (1899-1916), Kitāb al-Bad' wa-l-ta'rīkh, edited by C. Huart, Paris: Leroux.

al-Narshakhī, Muḥammad b. Ja'far b. Zakariyyā' (1954), Ta'rīkh Bukhārā: The History of Bukhara, translated by Richard N. Frye, Cambridge, MA.

al-Qalqashandī, Shihāb al-Dīn Aḥmad b. 'Alī (1407/1987), Șuḅ̣ al-a'shā fĩ șinā'at al-inshā', Beirut: Dār al-kutub al-'ilmiyya.

al-Raqīq al-Qayrawānī, Ibrāhīm b. al-Qāsim Abū Isḥāq (2010), Quṭb al-surūr fi awșāf al-anbidha wa-l-khumūr, edited by Sarra Barbouchi-Ben Yahia, Beirut/Baghdad: Manshūrāt al-jamal.

al-Rāwandī, Quṭb al-Dīn (1409 H), al-Kahrā'ij wa-l-jarā'iḥ, Qumm: Mu'assasat al-Imām al-Mahdī.

al-Ṣafadī, Șalāḥ al-Dīn Khalīl b. Aybek (1420 H), al-Wāfĩ bi-l-wafāyāt, edited by Aḥmad al-Arnā'ūṭ and Turkī Mușțafā, Beirut: Dār ị̣yā' al-turāth.

al-Sahmī, Ḥamza b. Yūsuf b. Ibrāhīm (1407 H), Ta'rīkh Jurjān, Beirut: 'Ālam al-kutub li-l-ṭibā'a wa-l-nashr.

al-Sam'ānī, Abū Sa'd 'Abd al-Karīm b. Muḥammad b. Manșūr al-Tamīmī (1408/1988), al-Ansāb, edited by 'Abdallāh 'Umar al-Bārūdī, Beirut: Dār al-jinān li-l-țibā'a wa-l-nashr wa-l-tawzī‘

al-Ṭabarī, Abū Ja'far Muḥammad b. Jarīr (1879-1901, repr. 1964), Ta'rīkh al-rusul wa-l-mulūk, edited by M. J. de Goeje, Leiden: Brill.

al-Ṭabarī al-Imāmī, Muḥammad b. Jarīr b. Rustum (1413 H), Dalā'il al-imāma, Qumm: Markaz al-țibā'a wa-l-nashr fī mu'assasat al-ba'tha.

al-Tanūkhī, Abū 'Alī al-Muḥassin b. 'Alī (1398/1978), al-Faraj ba'da al-shidda, edited by 'Abbūd al-Shālijī, Beirut: Dār șādir.

al-Tha'ālibī, 'Abd al-Malik b. Muḥammad b. Ismā'īl (1403/1983), Yatīmat al-dahr, edited by Mufĩd Muḥammad Qamḥiyya, Beirut: Dār al-kutub al-'ilmiyya.

al-Ṭihrānī, Āghā Buzurg (1403/1983), al-Dharīa ilā taṣānīf al-shī'a, Beirut: Dār al-aḍwā'. al-Ṭūsī, Abū Ja'far Muḥammad b. al-Ḥasan (1404 H), Ikhtiyār ma'rifat al-rijāl, edited by Mīr Dāmād al-Astarābādī and Mahdī al-Rajā'ī, Qumm: Mu'assasat āl al-bayt.

al-Ya'qūbī, Aḥmad b. Isḥāq b. Wāọị̣ (1892), Kitāb al-Buldān, edited by M. J. de Goeje, Leiden: Brill.

al-Ya'qūbī, Aḥmad b. Isḥāq b. Wāọiḥ (1882), Ta'rīkh, edited by M. Th. Houtsma, Leiden: Brill. Yāqūt al-Rūmī, Shihāb al-Dīn Abū 'Abdallāh al-Ḥamawī (1866-77), Mu'jam al-buldān, edited by $F$. Wüstenfeld, Leipzig.

Yāqūt al-Rūmī, Shihāb al-Dīn Abū 'Abdallāh al-Ḥamawī (1955-57), Mu'jam al-buldān, Beirut: Dār șādir.

Yāqūt al-Rūmī, Shihāb al-Dīn Abū 'Abdallāh al-Ḥamawī (1993), Mu 'jam al-udabā', edited by lḥsān 'Abbās, Beirut: Dār al-gharb al-islāmī.

al-Ziriklī, Khayr al-Dīn (1980), al-A'lām, Beirut: Dār al-'ilm li-l-malāyīn. 


\section{Studies}

Abbas, I. (1988), “Barmakids”, Encyclopaedia Iranica, 3, 806-809.

Adang, C. (1996a), Muslim Writers on Judaism and the Hebrew Bible: From Ibn Rabban to Ibn Hazm, Leiden/New York/Cologne: Brill.

Adang, C. (1996b), “Judaism and the Bible in al-Maqdisī's 'Kitāb al-Bad' wa-l-Ta'rīkh”, in: Hava Lazarus-Yafeh, ed., Muslim Authors on Jews and Judaism: The Jews among their Muslim Neighbours, Jerusalem: The Zalman Shazar Center for Jewish History, 59-68 [in Hebrew].

Agha, Salih Said (2003), The Revolution Which Toppled the Umayyads: Neither Arab nor 'Abbāsid, Leiden/Boston: Brill.

Amabe, F. (1995), The Emergence of the 'Abbāsid Autocracy: The 'Abbāsid Army, Khurāsān and Adharbayjān, Kyoto: Kyoto University Press

Ayalon, D. (1964), "The Military Reforms of Caliph al-Mu'tașim, their Background and Consequences," Jerusalem (provisional publication). First publication in Ayalon's collected studies: Islam and the Abode of War: Military Slaves and Islamic Adversaries, Aldershot: Variorum [collected studies series], no. I.

Ayalon, D. (1999), Eunuchs, Caliphs and Sultans: A Study in Power Relationships, Jerusalem: The Magness Press.

Barthold, W. (1928), Turkestan down to the Mongol Invasion, English translation by W. Barthold and H.A.R. Gibb (H.J.W. Gibb Memorial Series, New Series, no. 5), London.

Bearman, Peri J. et al. (1960-2006), The Encyclopaedia of Islam, 2nd ed., Leiden: Brill.

Beckwith, C. I. (1984), "Aspects of the Early History of the Central Asian Guard Corps in Islam", Archivum Eurasiae Medii Aevi 4: 29-43.

Blankinship, Khalid Y., trans. and ann. (1989), The History of al-Tabarī. The End of Expansion: The Caliphate of Hishām A.D. 724-738/A.H. 105-120. Vol. 25, Albany: State University of New York Press.

Bosworth, C. E., trans. and ann. (1989), The History of al-Tabarī. The 'Abbāsid Caliphate in Equilibrium. Vol. 30, Albany: State University of New York Press

Bosworth, C. E. (1994), "Abū Ḥaf̣ al-Kirmānī and the Rise of the Barmakids", Bulletin of the School of Oriental and African Studies 57: 268-282.

Bouvat, L. (1912), Les Barmécides d'après les historiens arabes et persans, Paris: Leroux.

Brockelmann, C., Geschichte der arabischen Litteratur, vol. 1 (Weimar, 1898); vol. 2 (Berlin, 1902). Second ed. 1945-49, Leiden: Brill. Supplementbände, vols. 1-3, 1937-42, Leiden: Brill.

Conrad, L. I. (2015), “Ibn A'tham and His History”, Al- 'Ușūr al-Wusțā 23: 87-125.

Crone, P. (1980), Slaves on Horses: The Evolution of the Islamic Polity, Cambridge: Cambridge University Press.

de la Vaissière, É. (2007), Samarcande et Samarra. Élites d'Asie centrale dans l'empire abbasside, Louvain: Peeters.

Elad, A. (1986), "The Siege of Wāsiṭ (132/749): Some Aspects of 'Abbāsid and 'Alīd Relations at the Beginning of 'Abbāsid Rule", in: Moshe Sharon, ed., Studies in Islāmic History and Civilization in Honour of Professor David Ayalon, Jerusalem/Leiden: Cana Publishing House/Brill, 59-90.

Elad, A. (1995), "Aspects of the Transition from the Umayyad to the 'Abbāsid Caliphate", Jerusalem Studies in Arabic and Islam 9: 89-132. 
Elad, A. (2005), “Mawālī in the Composition of al-Ma'mūn's Army: A Non-Arab Takeover?”, in: M. Bernards and John Nawas, eds., Patronate and Patronage in Early and Classical Islam, Leiden: Brill, 278-325.

Elad, A. (2010), “The Armies of al-Ma'mūn in Khurāsān (193/809-202/817-818): Recruitment of its Contingents and their Commanders and their Social-Ethnic Composition," Oriens 38: 35-76.

Elad, A. (2013), “Al-Ma'mūn's Military Units and Their Commanders up to the End of the Siege of Baghdad (195/810-198/813)”, in: Monique Bernards, ed., 'Abbasid Studies IV, Exeter: Short Run Press, 245-284.

Forand, P. G. (1962), "The Development of Military Slavery under the Abbasid Caliphs of the Ninth Century With Special Reference to the Reigns of Mu'tașim and Mu'taḍid”, PhD dissertation, Princeton University.

Friedmann, Y., trans. and ann. (1992), The History of al-Tabarī. The Battle of al-Qādisiyyah and the Conquest of Syria and Palestine. Vol. 12, Albany: State University of New York Press.

Gibb, H. A. R. (1923), The Arab Conquests in Central Asia, London: Royal Asiatic Society. Gil, M. (1992), A History of Palestine, 634-1099, translated by Ethel Broido, Cambridge: Cambridge University Press.

Goitein, S. D. (1982), “Jerusalem in the Arab Period (638-1099)”, in: L. I. Levine, ed., The Jerusalem Cathedra: Studies in the History, Archaeology, Geography and Ethnography of the Land of Israel, Jerusalem: Yad Iẓhak Ben-Zvi/Detroit: Wayne State University Press, 168-196.

Gordon, M. S. (2001), The Breaking of a Thousand Swords. A History of the Turkish Military of Samarra (A.H. 200-275/815-889 C.E.), Albany: State University of New York Press.

Haim, S. (1953), Persian English Dictionary, Tehran: Beroukhim.

Hawting, G. R. (2000), The First Dynasty of Islam. The Umayyad Caliphate AD 661-750, London/New York: Routledge.

Hinds, M., trans. and ann. (1990), The History of al-Ṭabarī. The Zenith of the Marwānid House. Vol. 23, Albany: State University of New York Press.

Ismā'īl, Osman S. A. (1966), "Mu'tașim and the Turks", Bulletin of the School of Oriental and African Studies 29: 12-24.

Kennedy, H. (1981), The Early 'Abbāsid Caliphate, London: Croom Helm.

Khālidī, T. (1976), “Mu'tazilite Historiography: Maqdisī's Kitāb al-Bad' wa-l-ta'rīkh”, Journal of Near Eastern Studies 35: 1-12.

Khalidi, T. (1994), Arabic Historical Thought in the Classical Period. Cambridge: Cambridge University Press.

Lambton, A. K. S. (1965), "Reflections on the Iqțā", in: George Maqdisi, ed., Arabic and Islamic Studies in Honour of H.A.R. Gibb, Cambridge, MA: Harvard University Press, 358376.

Lassner, J. (1980), The Shaping of 'Abbāsid Rule, Princeton, NJ: Princeton University Press.

Le Strange, G. (1890), Palestine under the Moslems, London.

Le Strange, G. (1905), The Lands of the Eastern Caliphate, Cambridge: Cambridge University Press.

Levy, R. (1969), The Social Structure of Islam, Cambridge: Cambridge University Press. 
Lindstedt, I. (2014), “Al-Madā'inī's Kitāb al-Dawla and the Death of Ibrāhīm al-Imām”, in: Jaakko Hämeen-Anttila and Ilkka Lindstedt, eds., Case Studies in Transmission, Münster: Ugarit-Verlag, 103-130.

Minorsky, V. (1942), Marwazi on China, The Turks and India. Arabic Text, London. Miquel, A. (1967), La géographie humaine du monde musulman, Paris/The Hague. Morony, M. (1988), “Bad' wa'l-Ta'rīkn”, Encyclopaedia Iranica, 3, 352-353.

Pipes, D. (1981), Slave Soldiers and Islam. The Genesis of the Military System, New Haven/London: Yale University Press.

Rosenthal, F. (1968), A History of Muslim Historiography, Leiden: Brill.

Saliba, George, trans. and ann. (1985), The History of al-Tabarī. The Crisis of the 'Abbāsid Caliphate. Vol. 25, Albany: State University of New York Press.

Sarkis, Yūsuf Ilyān (1346-49/1928-30), Mu'jam al-maṭbū'āt al-'arabiyya wa-l-mu'arraba, Cairo: Maktabat Sarkīs.

Sezgin, F. (1967), Geschichte des arabischen Schrifttums, vol. I, Leiden: Brill.

Shaban, M. A. (1976), Islamic History. A New Interpretation, A.D. 750-1055 (A.H. 132-448), Cambridge: Cambridge University Press.

Shaban, M. A. (1979), The 'Abbāsid Revolution, Cambridge: Cambridge University Press.

Sourdel, D. (1959-60), Le vizirat 'abbāside de 749 à 936 (132 à 324 de l'hégire), Damascus: Institut français de Damas.

Steingass, F. (1963), Persian-English Dictionary, London.

Van Ess, J. (1978), "Review of F. Sezgin, Geschichte des arabischen Schrifttums. Band II, Poesie bis ca. 430 H., Leiden. Brill, 1975”, Die Welt des Orients 9: 318-322.

Wellhausen, J. (1963), The Arab Kingdom and its Fall, translated by M. G. Weir, Beirut: Khayyat's Reprints.

Williams, J. A., trans. and ann. (1985), The History of al-Tabarī. The 'Abbāsid Revolution. Vol. 27, Albany: State University of New York Press.

Yonggyu, Lee (2004), "Seeking Loyalty: The Inner Asian Tradition of Personal Guards and its Influence in Persia and China," PhD dissertation, Harvard University.

Zakeri M. (1995), Sāsānid Soldiers in Early Muslim Society, Wiesbaden: Otto Harrassowitz. 